\title{
The Big Short: Short Selling Activity and Predictability in House Prices
}

\author{
Pedro A. C. Saffi* Carles Vergara-Alert ${ }^{\dagger}$
}

\begin{abstract}
We study how investors can use financial securities to speculate on the decrease of house prices. Unlike most asset types, houses are subject to high trading frictions and cannot be sold short directly. Using U.S. equity lending data from 2006 through 2013, we find evidence that an increase in the short selling activity of real estate investment trusts (REITs) forecasts a decrease in house prices in the subsequent month. The magnitude and significance of this effect vary with the geographical location of the REITs' underlying properties and with the housing cycle.
\end{abstract}

*Judge Business School, University of Cambridge, Trumpington Street, Cambridge, UK, CB2 1AG. Email: psaffi@jbs.cam.ac.uk. Tel.: +44 1223768491.

${ }^{\dagger}$ IESE Business School, University of Navarra; Av. Pearson 21, 08034 Barcelona, Spain. Email: cvergara@iese.edu. Tel.: +34 932534200. 


\section{Introduction}

Academics have uncovered numerous examples of how data on financial markets can be used to predict the behavior of variables in the real economy. ${ }_{1}^{1}$ However, while a substantial part of the literature focuses on forecasting macroeconomic fundamentals and commodity prices, less attention has been paid to the prediction of house prices. This is surprising because housing is one of the largest asset classes in the economy. Moreover, it is difficult to hedge against or speculate on declining house prices because houses are subject to short selling constraints and extremely high transaction costs. In this paper, we study how short selling liquid financial securities can be used to hedge the downside risk of house prices or to speculate on housing market downturns. We also construct an hedging strategy based on short selling intensity to reduce the downside risk of housing price decreases using REITs, showing that investors can limit their losses using RETIs' equity lending data.

The real estate market crash in 2008 provides a unique environment for this analysis. During this period, many investors set up large short positions to speculate on decreasing house prices $4^{2}$ Housing assets cannot be directly sold short. Consequently, if investors want to speculate on a decline in housing values, they must look for an alternative that is easy to short. We examine one channel that links financial securities (i.e., Real Estate Investment Trusts (REITs)) to real assets (i.e., housing assets) and study how measures of REIT stock lending activity can forecast house prices. Our hypotheses are based on the fact that investors can hedge, or speculate, on

\footnotetext{
${ }^{1}$ For example, (Liew and Vassalou (2000) $)$; Ang, Bekaert, and Wei (2007)); (Koijen, Van Hemert, and Van Nieuwerburgh (2009)); and Bailey and Chan (1993)) use financial market data to forecast economic growth, inflation, mortgage choices, and commodities, respectively.

${ }^{2}$ The book by Lewis (2010) describes how many hedge funds tried to profit from the U.S. real estate market crash. They used strategies such as selling futures on the Case-Shiller housing index, buying credit default swaps (CDSs), buying collateralized debt obligations (CDOs), and short selling real estate-related stocks (e.g., stocks of home-builders and government-sponsored enterprises). However, these strategies face problems (e.g., illiquid, thin trading or low correlation with housing returns) preventing them from being a feasible way to hedge or speculate on decreasing house prices.
} 
future house price movements through financial securities whose payoffs are linked to house prices. Because REITs are essentially portfolios of underlying real estate properties, they are plausibly related to fundamentals of housing markets. Thus, an increase in REIT short selling activity may forecast decreases in housing prices.

The lower transaction costs of REITs allow investors to reflect negative expectations about real estate prices more cheaply and quickly relative to directly trading in the housing markets. Investors with no exposure to house prices who want to speculate on, or hedge the risk of decreasing housing prices can short REIT stocks directly. It is generally cheap to short REITs in U.S. markets; the average REIT stock loan fee is equal to $0.23 \%$ per year, which is trivial in monthly terms. Thus, shorting REITs can provide a cost-effective trading strategy to reduce the downside risk of housing while investors attempt to sell the physical asset. The delay that occurs due to frictions as real asset prices adjust to new information is the channel that links current REIT returns to future house price changes. We develop and test three hypotheses based on this channel, using REIT stock lending activity, hand-collected information on the geographical location of REIT properties, and monthly housing returns from 2006 through 2013.

Our first hypothesis states that the correlation between REIT stock returns and housing returns varies with the state of the housing market cycle. We classify each month in our sample as being a "boom", an "average", or a "downturn" period. $!^{3}$ We find that this correlation is close to zero during "average" periods of the housing market cycle. However, the correlation is significantly positive during housing market downturns. These results suggest that short selling REITs can be a good strategy to speculate on housing market downturns and hedge the downside risk in housing markets. Specifically, the correlation between the Federal Housing Finance

\footnotetext{
${ }^{3}$ We define "boom" and "downturn" periods as months when housing returns are 1.64 standard deviations above and below their historical sample mean, respectively. "Average" periods denote months in which housing returns are lower than 1.64 standard deviations above and higher than 1.64 standard deviations below their historical mean up to the month in question.
} 
Agency (FHFA) housing indices returns and REIT returns conditional on being in a housing market downturn for the period 1991 through 2013 is 0.208 . The equivalent unconditional correlation is 0.058 .

Our second hypothesis relates to short selling activity and house price predictability. If investors expect that house prices will decrease, they can use correlated securities to act upon these expectations for hedging or speculative purposes. We document that an increase in REIT short selling activity forecasts a decrease in the following month's house prices. Using a panel vector autoregression (PVAR) reduced-form model (Abrigo and Love (2016) ), we find that a one standard deviation increase in the short selling activity of REITs - measured by stock utilization leads to a 0.74 standard deviation decrease in house price returns..$^{4}$ While the PVAR model controls for the simultaneity between housing returns, REIT returns, and REIT short sales activity, our results are also robust to controls for bid-ask spreads, turnover and the term spread.

Our third hypothesis is related to the geographical of location of REIT properties and their stock lending activity. The large variation in house prices across U.S. regions during the financial crisis should also lead to differences in the short selling activity of REITs. We hypothesize that we can improve the forecasts of house prices across different areas by examining the short selling activity of REITs and the location of their properties. We find that REITs invested in properties located in areas that experienced a housing boom during the expansion cycle in the 2000s are more sensitive to increases in short-selling activity than REITs invested in properties located in areas that did not experience a housing boom. We find that a one standard deviation increase in the utilization of REITs' with properties in regions that have experienced a relative housing boom forecasts a 0.04 standard deviations decrease in house prices in the following

\footnotetext{
${ }^{4}$ Utilization, defined as the fraction of REIT stock loans divided by lendable supply, has a mean equal to $18.62 \%$ and a standard deviation of $8.05 \%$. The mean of monthly house price returns during the sample period is $-0.11 \%$ and its standard deviation is $0.70 \%$.
} 
month. Furthermore, we do not find any effect for REITs with properties in regions that have not experienced a housing boom.

Using REITs to study how the trading activity of financial securities predicts house prices presents many advantages. First, through their dividends and capital appreciation, REITs provide a direct link between rents and capital gains in real estate markets. REITs are corporations that invest in real estate, through either properties or mortgages. They receive favorable tax treatment but are required to distribute $90 \%$ of their taxable income to their shareholders. Most REITs opt to pay out all of their income for several years. They are designed to provide a structure for investing in real estate similar to the one provided by mutual funds for investing in stocks. 5 Second, the information about the properties managed by each REIT is publicly available. Therefore, we can establish the explicit connection between those properties and house price indices in different geographical areas. Specifically, we classify REITs in different geographical areas according to the location of their properties and link stock-level data to the house prices of each area. Third, unlike securities used in other trading strategies (e.g., selling futures on the Case-Shiller index), REITs are very liquid. Fourth, REITs possess a well-functioning equity lending market for investors who need to borrow shares for delivery following a short sale. Fifth, REITs manage a large amount of assets that are representative of the real estate markets. As of January 2014, there are 204 publicly-traded REITs present in the Center for Research in Security Prices (CRSP) database, with a total market capitalization of $\$ 719$ billion.

Figure 1 provides our initial motivation. It displays the time series of REITs' short selling activity in terms of lendable supply (Supply) and equity loan demand (On Loan) beginning in June 2006 as a fraction of the aggregate REITs' total market capitalization (right axis), and

\footnotetext{
${ }^{5}$ REITs invest in different property types such as residential, retail, office, healthcare, hotels, industrial, and self-storage. Residential properties are part of the housing markets, while the other property types are classified as commercial real estate. Our results are robust to using data from all REITs regardless of the property type or from residential REITs only.
} 
as the cumulative housing returns for REITs (left axis) grouped according to the geographical location of their properties (housing returns are available for a longer period than short sal). Panel A shows the short selling activity and cumulative housing returns for REITs with more than $50 \%$ of their properties located in one of the U.S. Census regions (i.e., Northeast (Region 1), Midwest (Region 2), South (Region 3), and West (Region 4)). House prices almost doubled in the Northeast and more than doubled in the West region from 2000 through 2007, while the increase in prices was much lower in the Midwest and South regions for the same period. We also observe that REITs with properties located in areas that experienced a big run-up in house prices (e.g., REITs with properties in the West and Northeast regions) presented higher values of the on loan and lending supply measures than REITs with properties located in areas that experienced a small run-up in house prices (e.g., REITs with properties in the Midwest and South regions). The loan demand of REITs with properties in the Midwest and South regions is mostly flat throughout our sample period, while there is a large increase of loan demand for REITs with properties in the West or the Northeast regions before Lehman Brothers' bankruptcy in September 2008. For instance, the loan demand was very similar for all the REITs in March 2007. It was around $2 \%$ of the total sector market capitalization. However, loan demand for REITs with properties in the Northeast and the West regions almost tripled by September 2007.

\section{[INSERT FIGURE[1]HERE]}

Panel B of Figure 1 is similar to Panel A but splits according to Housing Boom areas No Housing Boom areas. Housing Boom areas are defined as those in which house prices had a cumulative run-up of $75 \%$ or more during the period of January 2000 through December 2007,

while No Housing Boom areas are those in which prices increased by less than $75 \%$. The aggregate lending supply of REITs with most of their properties in Housing Boom Areas was around $33 \%$ in July 2007, similar to the $30 \%$ observed for REITs properties in areas with no 
housing boom. The amount of REITs lent out to investors more than doubled from January 2007 through September 2008, going from 5\% to above 13\% of market capitalization. Overall, this figure exhibits that short selling activity is higher for REITs with most of their properties located in Housing Boom areas than for REITs with most of their properties located in No Housing Boom areas.

\section{Literature Review}

Our findings relate to the intersection of two research areas. First, our paper contributes to the literature on short selling activity and price predictability. Table 1 shows the gap that

our paper fills in the literature. Some authors (e.g., Asquith and Meulbroek (1995)), Jones and Lamont (2002)); Desai, Ramesh, Thiagarajan, and Balachandran (2002)); Boehme, Danielsen, and Sorescu (2006)); Cohen, Diether, and Malloy (2007)); Nagel (2005)); Boehmer, Huszár, and Jordan (2010)]; Rapach, Ringgenberg, and Zhou (2016)); and Huszár, Tan, and Zhang (2017)) ) explore the link between short interest and future stock returns. Research that specifically focuses on REIT short selling activity is very thin. Li and Yung (2004)) analyze the determinants of REIT short interest and find a negative relationship between short interest and returns. Their results are significant only for the highest decile of REIT short interest. More recently, Blau, Hill, and Wang (2011)) document that short selling activity is high in REITs that perform well and low in underperforming REITs. Chen, Downs, and Patterson (2012)) consider heterogeneous beliefs and use the full cross-section of REIT short interest to test for stock overvaluation. We are not aware of any study that has considered the link between REIT equity lending data and the underlying housing market. Our results show that REIT short in- 
terest does not provide strong predictability. $\left.\right|^{6}$ However, we find that the use of measures that include information about the supply of REIT shares for short selling purposes (e.g., on loan, utilization, and fees) improves the predictability of house prices.

\section{[INSERT TABLE[1]HERE]}

Second, we contribute to the literature on market efficiency by studying how frictions in housing markets can be exploited to speculate on decreasing house prices through financial securities. Frictions in housing markets prevent negative information from being rapidly incorporated into house prices. As a result, house prices are predictable (e.g., see the predictability tests in Campbell, Davis, Gallin, and Martin (2009)) and Corradin, Fillat, and Vergara-Alert (2014)), and a review by Ghysels, Plazzi, Torous, and Valkanov (2012)).) Studies by Gyourko and Keim (1992)); Barkham and Geltner (1995)); Naranjo and Ling (1997)); Benjamin, Sirmans, and Zietz (2001)); Pagliari, Scherer, and Monopoli (2005)); and Riddiough, Moriarty, and Yeatman (2005)) analyze how REIT returns can forecast real estate prices (i.e., how financial securities data can forecast real estate returns) and show evidence of real estate market inefficiency. In particular, this literature documents that price information takes over a year to be reflect by unsecuritized markets. Row (3) in Table 1 summarizes the main characteristics of the empirical approaches used in these papers.

Our paper differs from this literature along two dimensions. First, all these studies use data from appraisals (i.e., National Council of Real Estate Investment Fiduciaries (NCREIF) indices). Consequently, the delayed incorporation of information into NCREIF indices due to infrequent property appraisals is the reason for the predictability in real estate prices observed in the data. Geltner (1998)) documents that NCREIF indices have two sources of error: random

\footnotetext{
[Cohen, Diether, and Malloy (2007)] show that short interest is not a sufficient statistic to measure shorting demand. For instance, low short interest could be due to lack of demand or high short selling constraints.
} 
appraisal error and the lagging of appraised values. We employ repeated sales indices of houses (i.e., FHFA indices) instead of appraisal-based indices of income-producing commercial real estate properties (i.e., NCREIF indices). Second, this literature does not consider the geographical location of the real estate properties owned by the REITs to exploit cross-section variation. As a result, our findings are incremental to the papers listed in rows (2) and (3) of Table 1 .

\section{Hypotheses Development}

Our hypotheses build on the idea that frictions in the real estate markets prevent negative information (i.e., negative demand shocks to commercial or housing markets) from being instantaneously incorporated into prices. As a consequence, investors try to sell short financial securities (e.g., REITs) that are correlated with the physical asset's income stream, incurring lower trading costs. Variables that indicate an increase in the short selling activity of REITs capture expectations about future prices and, consequentially, about expected decreases in house prices (e.g., Asquith and Meulbroek (1995)); Cohen, Diether, and Malloy (2007))). Therefore, if investors expect house prices to decrease but cannot sell houses outright due to trading frictions, shorting REITs might be used as a substitute strategy. While it is beyond the scope of our paper to provide a structural model of the dynamics of REITs and house prices, we present a reduced-form generalization of Kyle's (1985) model to theoretically motivate our testable hypothesis.

\section{Theoretical Motivation}

In this subsection, we set up a stylized conceptual framework to illustrate how REITs, which typically hold commercial property, can be used to hedge housing. There are two channels by 
which commercial and housing assets are linked. First, these assets can be seen as complementary goods: a negative demand shock to housing markets (e.g., an economic shock that lowers employment) is also likely to reduce the demand for commercial real estate. Second, a negative demand shock for housing also has the effect of reducing the demand for common factors of production between commercial real estate and housing (e.g., available land) and their prices. These inputs are used in the production of commercial real estate goods, leading to a positive supply shock and, all else equal, to lower commercial estate prices. Empirically, the correlation between commercial real estate and housing (e.g., Gyourko (2009)) and Geltner, Miller, Clayton, and Eichholtz (2001)) ), as well as the correlation between real estate markets and the business cycle (e.g., Green (1997)) and Quan and Titman (1999))), have been widely documented in the real estate literature. In summary, there are several theoretical channels by which commercial and housing prices are linked (e.g., Geltner, Miller, Clayton, and Eichholtz (2001)) and Spiegel (2001)) $)$.

We include this positive covariance between commercial real estate and house prices into an equilibrium model of REIT stock trading that generalizes the model in Kyle (1985), ] W We assume that there is a single risk neutral informed trader - a speculator - with superior information about the real estate markets, who can trade shares of REITs with risk neutral uninformed liquidity traders. Informed and uninformed traders submit orders to buy and sell stocks of REITs to a risk-neutral market-maker. The market-maker observes the aggregate order flow and sets a price to clear the market. Because the order flow includes both informed and uninformed trades, it provides an imperfect signal to the market maker about the information in the real estate markets that is incorporated into prices. Risk-neutral uninformed investors trade for nonspeculative reasons. They demand a quantity $\widetilde{u}$, which is drawn from an independent normal distribution with mean 0 and variance $\sigma_{u}^{2}$. The informed trader knows the distribution of $\widetilde{u}$ but

\footnotetext{
${ }^{7}$ The full model is set out in more detail in the Online Appendix.
} 
not its actual realization.

The model has three stages with one round of trading. In the first stage, the informed trader learns private information about the ex post commercial rents, $\widetilde{P_{t}^{C}}$, and the ex post liquidation value, $\widetilde{V_{t}^{C}} 8$ Because of their special tax treatment, REITs are required to pay a high fraction of their taxable income derived from rents as dividends $\left(\alpha_{P}\right)$, as well as a high fraction of any capital gains obtained from selling properties $\left(\alpha_{V}\right)$. Therefore, REIT dividends are $\alpha_{P} \widetilde{P_{t}^{C}}+$ $\alpha_{V} \widetilde{V_{t}^{C}}$, where $\alpha_{P}$ and $\alpha_{V}$ are constant. The trader can estimate the value of the stock of REITs, $\widetilde{v}$, by calculating the present value of these payoffs as $\widetilde{v}=\left(\alpha_{P} \widetilde{P_{t}^{C}}+\alpha_{V} \widetilde{V_{t}^{C}}\right) /\left(1+R^{C}\right)$, where $R^{C}$ is the discount rate. Similarly, she can estimate housing prices as the present value of the cash flows generated by housing assets, $\widetilde{P_{t}^{H}}$, and their liquidation value, $\widetilde{V_{t}^{H}}$; that is, $\widetilde{h}=$ $\left(\alpha_{H} \widetilde{P_{t}^{H}}+\alpha_{V} \widetilde{V_{t}^{H}}\right) /\left(1+R^{H}\right)$. We assume that discount rates $R^{C}$ and $R^{H}$ are constant and known by the informed trader. In the second stage, the trade intensity of the uninformed traders, $\widetilde{u}$, is realized. Without knowing about $\widetilde{u}$, the informed trader chooses her demand for REIT shares, $\widetilde{x}$, that maximizes her utility conditional on her private information about the real estate markets. The choice of $\widetilde{x}$ is the channel that drives the incorporation of information into security prices. In the third stage, the market maker observes the aggregate net order flow, $\widetilde{x}+\widetilde{u}$, and sets a single stock price for the REIT, $P^{R E I T}$, to clear the market. This price must satisfy $P^{R E I T}(\widetilde{x}+\widetilde{u})=E[\widetilde{v} \mid \widetilde{x}+\widetilde{u}]$.

In equilibrium, the informed trader's order strategy, $\widetilde{x}(\widetilde{v})$, is given by

$$
\widetilde{x}(\widetilde{v})=\left[\frac{\sigma_{v}}{\sigma_{u}}\right]^{-1}[\widetilde{v}-E(\widetilde{v})],
$$

\footnotetext{
${ }^{8}$ For simplicity, we assume that the demand shocks for commercial real estate $D_{t}^{C}$ are such that the equilibrium rents are normally distributed with mean $\mu_{P}$ and variance $\sigma_{P}^{2}$. Similarly, we consider that each REIT collects rents for one period and sells its real estate properties during the next period at a price drawn from a normal distribution with mean $\mu_{V}$ and variance $\sigma_{V}^{2}$. We also assume that these two normal distributions are independent.
} 
the price $P^{R E I T}(\widetilde{x}+\widetilde{u})$ that the market maker sets up is

$$
P^{R E I T}(\widetilde{x}+\widetilde{u})=E(\widetilde{v})+\frac{1}{2} \frac{\sigma_{v}}{\sigma_{u}}(\widetilde{x}+\widetilde{u})
$$

where $\sigma_{v}^{2}=\left[\frac{\alpha_{P}}{1+R^{C}}\right]^{2} \sigma_{P}^{2}+\left[\frac{\alpha_{V}}{1+R^{C}}\right]^{2} \sigma_{V}^{2}, E(\widetilde{v})=\frac{\alpha_{C} p_{C}}{1+R^{C}}+\frac{\alpha_{V} p_{V}}{1+R^{C}}$, and the correlation between REITs and house prices is

$$
\operatorname{Cov}\left(P^{R E I T}, \widetilde{h}\right)=\frac{\alpha_{P}}{2\left(1+R^{C}\right)\left(1+R^{H}\right)} \operatorname{Cov}\left(P^{C}, P^{H}\right)+\frac{\alpha_{V}}{2\left(1+R^{C}\right)\left(1+R^{H}\right)} \operatorname{Cov}\left(V^{C}, V^{H}\right) .
$$

A few results arise from this equilibrium.9 First, equation (1) shows that if the informed trader receives pessimistic information about rents and real estate prices that makes her current valuation of the stock of REITs, $\widetilde{v}$, to be lower than the expected (mean) value of $\widetilde{v}$, then she places a negative (i.e., short-selling) order. The size of the short-selling order increases with the volatility of the trades of the uninformed traders, $\sigma_{u}$, and decreases with the volatility of the signal of the value of the stock of REITs that the informed trader obtains. Second, the REIT's stock price in $(2)$ is linear with the order flow $(\widetilde{x}+\widetilde{u})$. A reduction in the demand for stock by either informed or uninformed traders induces the market maker to infer a lower valuation and leads to lower equilibrium prices. Thus, we expect that a higher intensity of short selling will be associated with lower REIT stock prices. Third, the impact of the order flow on REIT stock prices depends on the variance of the real estate market fundamentals. The second term in the right-hand side of equation (2) shows that the variance of the value of the REIT stock, $\sigma_{v}^{2}$, increases the adjustment in REIT prices to reflect the information contained in the order flow. Besides, the variance of the value of the REIT stock depends on the variance of rents, $\sigma_{P}^{2}$, and real estate assets, $\sigma_{C}^{2}$, in the geographical area where its properties are located. Therefore, a higher variance in a particular area will increase the impact of order flow on REITs

\footnotetext{
${ }^{9}$ The Online Appendix includes the details about the equilibrium of this model.
} 
prices. More specifically, we expect short selling to have a larger impact in areas with higher uncertainty in the underlying real estate fundamentals. Finally, equation (3) shows how the stock price of REITs (i.e., financial securities) are correlated with housing (i.e., real assets) due to the correlation between commercial and housing rents and the correlation between the liquidation values of commercial and housing assets.

\section{Testable Hypotheses}

Our first hypothesis focuses on the time-varying correlation between REIT returns and housing returns. The historical unconditional correlation between these two variables is very low. We conjecture that this correlation increases significantly during housing market downturns, which is formalized in Hypothesis 1. Comparative statistics for housing market booms versus housing market downturns (or busts) using equation (3) support this conjecture.

Hypothesis 1 The correlation between REIT returns and housing returns is higher during housing market downturns.

Let $R_{i, t}^{R E}$ denote the return on house prices in the geographical area $i$ at time $t, R_{i, t}^{R E I T}$ denote the return on REIT stock prices in the geographical area $i$ at time $t$, and $D_{i, t}^{B u s t}$ denote a dummy variable that takes the value of one when the housing market in area $i$ is in a downturn and zero otherwise. We test whether the coefficient $\beta_{3}$ of the following regression model is significantly positive:

$$
R_{i, t}^{R E}=\alpha+\beta_{1} \cdot R_{i, t}^{R E I T}+\beta_{2} \cdot D_{i, t}^{\text {Bust }}+\beta_{3} \cdot R_{i, t}^{R E I T} \cdot D_{i, t}^{\text {Bust }}+\epsilon_{i, t}
$$

where $\epsilon_{t}$ is the error term. A positive coefficient of the interaction term, $\beta_{3}$, indicates that the correlation between the variables $R_{i, t}^{R E}$ and $R_{i, t}^{R E I T}$ is higher when the dummy variable $D_{i, t}^{\text {Bust }}$ is one; that is, during housing market downturns. 
A vast body of empirical literature on real estate explores the dynamics of REIT returns and links them to the returns of real estate assets. For example, Clayton and MacKinnon (2001)) and Lee, Lee, and Chiang (2008)) show that REITs only begin to exhibit a direct link to real estate returns in the 1990s. Oikarinen, Hoesli, and Serrano (2011), Hoesli and Oikarinen (2012)) and Boudry, Coulson, Kallberg, and Liu (2012)) show that the dynamics of the long-run REIT market are more closely related to the real estate markets than to stock markets. Morawski, Rehkugler, and Füss (2008)) find that REIT stocks lead the private property markets. Yunus et al. (2012)) document international evidence of the relationship between REIT returns and the return of real estate assets.

Hypothesis 2 An increase in REIT short selling activity forecasts a reduction in the next month's house prices.

The link between the real asset (i.e., housing) and the financial security (i.e., REITs) is the basis of our empirical tests on whether proxies for short selling activity can be used to forecast house prices. Housing assets cannot be directly sold short. Consequently, if investors want to speculate on a decline in housing values, then they must look for an alternative that is easy to short. Thus, an increase in REIT short selling activity indicates that investors are betting on decreases in REIT stock prices, which are driven by the fundamental value of real estate markets. Notice that the conditional expectation of $\widetilde{h}$ given $\widetilde{x}$ is

$$
E[\widetilde{h} \mid \widetilde{x}=x]=E(\widetilde{h})+\left[\frac{\sigma_{u}^{2}}{\sigma_{v}^{2}}\right]^{-\frac{1}{2}} x .
$$

That is, there exists a linear relationship between house prices and the informed trader demand for REIT shares. 
This equation shows that an increase in short selling by informed investors (i.e., a decrease in the order flow, $x$ ) induces a downward revision of beliefs about the value of the real asset (i.e., a decrease in the conditional expectation of the housing value, $E[\widetilde{h} \mid \widetilde{x}=x]$ ). Equation (5) also shows that the higher the uncertainty about the underlying real estate markets, $\sigma_{v}^{2}$, the larger the impact that the order flow, $x$, will have on the conditional expectation about the value of the real estate asset, $h .10$

Finally, we study the geographical cross-section of short selling activity. While average house prices decreased in all U.S. areas and REIT short selling activity increased during the recent housing bust, Figure 1 shows that these effects differed across regions. REITs with a majority of properties located in Boom areas present higher short selling activity than REITs with their majority of properties in No Boom areas. Moreover, equation (1) shows that the effect of REIT short selling activity on house prices is stronger in areas that display higher volatility or higher $\sigma_{v}^{2}$ (e.g., areas that have experienced a larger price run-up). Therefore, areas that experienced smaller house price run-ups before the financial crisis in 2008 should be less affected by increases in short selling activity. Our third and last hypothesis tests whether areas that experienced higher house price run-ups before the financial crisis in 2008 were more affected by increases in short selling activity. Hypothesis 3 formalizes this conjecture.

Hypothesis 3 Short sales of REITs with properties located in areas with a larger price run-up during the period January 2000-December 2007 forecast a higher decrease in house prices.

The economic intuition goes as follows. If house prices in some areas had increased sharply and a major correction in prices is expected, then we would expect investors to take action. Investors should take short positions on financial securities that are correlated with the housing

\footnotetext{
${ }^{10}$ Recall that the variance of the value of the REIT stock depends on the variance of rents, $\sigma_{P}^{2}$, and real estate assets, $\sigma_{V}^{2}$. These variables depend on the business cycle.
} 
market in bad times. Because REIT returns are highly correlated with housing returns during housing market downturns (i.e., Hypothesis 1), an increase in REIT short selling activity forecasts a reduction in the next month's house prices (i.e., Hypothesis 2) and should indicate an even stronger relationship in areas with a higher expected housing market downturns (i.e., areas with a housing boom).

\section{Data and Empirical Methodology}

\section{Description of the Data}

We use United States data due to the availability of information about REIT short selling activity, along with house price indices for different geographical region at monthly frequencies. We match data from the CRSP-Ziman REIT database to a proprietary dataset of lending supply postings and stock loans provided by Markit. Saffi and Sigurdsson (2011)) and Porras Prado, Saffi, and Sturgess (2016)] provide further details on these equity lending data. The information is collected daily from 125 custodians and 32 prime brokers; Markit estimates that the data cover more than $85 \%$ of global equity lending. Out of the 257 REITs present in CRSP from July 2006 through July 2013, we can match 245 to our equity lending data. We also collect information on REIT returns, market capitalization, bid-ask spreads, average daily turnover, and short interest data from CRSP/Compustat.

The equity lending data present daily information on the quantity of shares available to borrow, the shares effectively lent out, and the loan-weighted average fee ${ }^{11}$ We employ three main

\footnotetext{
${ }^{11}$ Note that equity loans are not a perfect measure of short selling since they might be used as part of tax-arbitrage strategies or hedging strategies (see Christoffersen, Geczy, and Musto (2005)); however the vast majority of loans are made with the purpose of delivering shares following a short sale.)
} 
variables to capture short selling intensity: (i) On Loan is the value of shares lent out relative to market capitalization of REITs with property holdings in that area at time $t$-1, (ii) Utilization is defined as the amount on loan divided by the value of the supply of shares available to borrow, and (iii) Short Interest Ratio is the value of shares sold short reported in Compustat relative to the total market capitalization ${ }_{12}^{12}$ Dechow, Hutton, Meulbroek, and Sloan (2001)), Chen and Singal (2003)), and Arnold, Butler, Crack, and Zhang (2005)) construct similar measures for their studies, but ours is the first to use REIT equity lending data as a proxy for short selling activity.

We use the U.S. Federal Housing Finance Agency (FHFA) House Price Indices as our main measures of house prices. They are weighted, repeat-sales indices and are available at a monthly frequency for the aggregate U.S. housing market and each U.S. Census Divisions ${ }^{13}$ We obtain data on Treasury bond yields from Datastream, defining Term Spread $(10 y-3 m)$ as the difference between the 10-year and the 3-month Treasury bond yields. We also use the Moody's/RCA Commercial Property Price Indices (CPPI) in our empirical analyses. They are are weighted, repeat-sales indices, which are computed using contemporaneous transaction-price-based data on private deals. There are specific CPPI indices for different property types (e.g., apartment, retail, industrial, office-central, office-suburban, and hotel). The CPPI data are available at a monthly frequency only for the aggregate U.S. housing market, not for U.S. metropolitan areas.

Given that REITs have a wide range of investment strategies (e.g., commercial, residential, or industrial properties), we perform our tests using three alternative sets of REITs. The baseline set (All REITs) uses all REITs included in the CRSP-Ziman database, regardless of whether they focus on residential or commercial real estate. We find even stronger results if we use

\footnotetext{
${ }^{12}$ On Loan does not take into account the lendable supply available. Thus, an increase in On Loan may be due to a decrease in short selling constraints rather than to the arrival of negative information. Utilization can better capture the intensity of short sales constraints.

${ }^{13}$ This is the largest level of granularity available at the monthly frequency. We use the purchase-only indices.
} 
only Residential REITs (i.e. those with the property type variable PTYPE $=8$ in the CRSPZiman database). Finally, we match apartments-focused REITs (i.e., those with $P T Y P E=8$ and $P S U B=2)$ to forecast the CPPI Apartment Index as an additional robustness test. These three sets of REITs (All REITs, Residential REITs, Apartments-only REITs) and two real estate indices (the FHFA housing price index and the apartments CPPI) provide us with alternative ways to test Hypothesis 2.

Table 2 presents monthly summary statistics for the variables used in our empirical analyses. There is an average of 114 REITs with an average market capitalization of $\$ 5.13$ billion. The average equal-weighted monthly individual REIT's return in the period is positive $(0.99 \%)$ but it has a high standard deviation (7.86\%), reflecting the large price fluctuations observed during our sample period. Examining the short selling measures, we find that an average of $29 \%$ of REIT market capitalization is available to borrow (Supply), with $6.41 \%$ actually being lent out. The large slack supply available to borrow is captured by the $18.62 \%$ average value for utilization, meaning that less than a quarter of lendable shares is effectively lent out, similar to numbers observed in the aggregate U.S. stock market (Porras Prado, Saffi, and Sturgess (2016))).

[INSERT TABLE[2]HERE]

\section{Classification of REITs According to the Location of Their Properties}

We match the returns on the FHFA House Price Indices calculated for each U.S. Census region with REIT data in the CRSP-Ziman database. We hand-collect data on the composition of each REIT property portfolio and classify all REITs into ten groups based on the geographical location of their underlying properties using U.S. Census regions. First, U.S. states are divided into four main regions: West (Hawaii, Alaska, Washington, Oregon, California, Mon- 
tana, Idaho, Wyoming, Nevada, Utah, Colorado, Arizona, New Mexico); Northeast (Maine, New Hampshire, Vermont, Massachusetts, Rhode Island, Connecticut, New York, New Jersey, Pennsylvania); Midwest (North Dakota, South Dakota, Minnesota, Nebraska, Iowa, Kansas, Missouri, Michigan, Wisconsin, Illinois, Indiana, Ohio); and South (Kentucky, Tennessee, Mississippi, Alabama, Delaware, Maryland, District of Columbia, Virginia, West Virginia, North Carolina, South Carolina, Georgia, Florida, Oklahoma, Arkansas, Texas, Louisiana). We examine the U.S. Census region level because too few REITs hold properties that are confined mainly to a single U.S. state. Most of the REITs are diversified across several states and it is not possible to classify REITs at the U.S. state level according to the locations of their properties.

We allocate each REIT to a particular state and region according to the location of its properties. If more than $50 \%$ of a REIT's investment are located in one of the four U.S. Census regions, then it is classified as part of that specific regional group; that is, Northeast, Midwest, South, and West. If no single region contains more than $50 \%$ of the REIT's properties, but the REIT has more than $50 \%$ of its properties in a combination of two regions, we then create a group for the specific two-region combination. The pairs Northeast+South, Northeast+West, Midwest+South, and South+West contain at least one REIT. Mixing single regions with mixed regions produces eight regional groups. If the REIT has properties spanning different regions but no combination of two regions account for more than $50 \%$ of the REIT's properties, then the REIT is classified as Diversified. REITs that do not fall into any of the categories above are excluded from our multivariate analysis.

Finally, because our main goal is to examine differences between REITs exposed to areas that have experienced a boom in house prices and those that did not, we group the REITs within the eight regional groups described above two categories: Boom and No Boom areas. Boom areas are defined as those in which house prices had a cumulative run-up equal to or greater $75 \%$ during the period January through December 2007, while No Boom areas are those 
areas in which prices increased by less than $75 \%$. These criteria aim to separate regions that experienced a large price run-up during the expansion cycle of the housing markets in the 2000s (mostly in the Northeast and the West) from those that did not (mostly in the Midwest and the South). Our results are robust to alternative choices of the starting month to compute the price run-up (e.g, January 2000), the ending month that represents a month at the peak of the housing cycle (e.g., December 2007), and to alternative levels of cumulative price increases (e.g., 75\%).

Table 3 displays descriptive statistics for the number of REITs in each group per month. From Panel A, the majority of REITs (i.e., an average of 62.30 observations per month) have geographically diversified investments. Our dataset contains an average of 4.04, 1.00, 13.24, and 4.93 REITs each month within the categories Northeast, Midwest, South, and West, respectively. South+West is the most populated category within those that contain REITs with most of their properties in two regions. We have dropped from our sample REITs that invest only in mortgages and unclassified REITs. In Panel B, we report that the average number of REITs with properties located in No Boom areas is 25.39, approximately twice as many as those in Boom areas.

\section{[INSERT TABLE[3 HERE]}

Moreover, Table 3 shows the link between REIT short selling activity and the geographical location of their properties. It shows that REITs with a majority of properties located in the Northeast and the West have higher Supply (35.29\% and 35.38\%, respectively) and On Loan $(8.08 \%$ and $10.29 \%)$ than those with a majority of properties located in the Midwest and South (18.17\% and $29.31 \%$ Supply, and $2.81 \%$ and $7.42 \%$ On Loan, respectively). At the aggregate level, REITs with a majority of properties located in Boom areas present higher Supply (35.22\%), On Loan(10.30\%) and Short Interest Ratio $(8.75 \%)$ than the REITs with a majority of properties located in No Boom areas $(28.36 \%, 7.44 \%$, and $6.85 \%$, respectively). 


\section{Measures of Housing Returns}

Before describing our empirical methodology, it is important to discuss the validity of the measures of housing returns that we use. First, we use FHFA indices, which track singlefamily residential property values, as the main measure for computing the housing returns in our analyses. We use purchase-only indices, which include only transaction prices (i.e., they do not include appraisals on mortgage refinances). These repeat-sales indices minimize the lag and smoothing of housing data because they are based on transaction prices rather than on appraised values. It is also important to note that most of the assets used to compute the purchase-only FHFA indices are owner-occupied properties rather than rental properties.

We also use the Moodys/RCA Commercial Property Price Index (CPPI) as an additional robustness measure to calculate housing returns.$^{14}$ Because we focus our study on the prediction of house prices, we specifically use the apartment CPPI. As with the purchase-only FHFA index, this index is based on transaction prices for residential properties. However, the apartment CPPI includes transaction prices only of renter-occupied residential properties. We observe a strong relationship between renter and owner-occupied residential property values. Finally, the monthly reported value of the CPPI is explicitly a lagged moving average of the values for the preceding three months. However, our PVAR approach accounts for the autocorrelation of the housing returns and, therefore, addresses any problems caused by the lagged moving average 15

\section{Empirical Methodology}

Standard OLS regressions do not account for the possible reverse causality of the explanatory variables. For instance, REIT short selling activity, housing returns and REITs returns

\footnotetext{
${ }^{14}$ See Sun, Yang, and Zhao (2012)] for a highly detailed analysis of commercial real estate indices.

${ }^{15}$ Our results hold for the PVAR model with two, three and four lags.
} 
might be endogenously determined because they all depend on future expectations about house prices. To address this issue, our main empirical setup is based on a panel vector autoregression (PVAR) reduced-form model (Abrigo and Love (2016) ). This approach allows us to estimate the joint dynamics of house price returns, REIT returns, and short selling variables as in HoltzEakin, Newey, and Rosen (1988)) and Pesaran and Smith (1995)). Although PVAR models are commonly used in the macroeconomic literature, they are not widely used in finance and real estate economics. The use of a PVAR model has three advantages in our setup: (i) it captures the dynamic relationships among all the time series in the analysis, (ii) it allows for heterogeneity among different panel units, and (iii) the reduced-form specification assumes that all dependent variables in the system are endogenously determined.

For a given set of variables, the first-order PVAR specification is given by:

$$
z_{i, t}=\Gamma_{0}+\Gamma_{1} z_{i, t-1}+\Gamma_{2} x_{i, t-1}+f_{i}+\theta_{t}+\epsilon_{i, t}
$$

where $z_{i, t}$ denotes the vector of endogenously determined variables (i.e., short selling activity, $R^{R E I T}$, and $R^{F H F A}$ ); $x_{i, t-1}$ denotes exogenous control variables (i.e., REIT bid-ask spread, REIT turnover, and the term spread of interest rates); and $\epsilon_{i, t}$ is the error term. Let $i$ denote each group according to the geographical location of REIT properties and let $t$ denote time. Group fixed-effects $\left(f_{i}\right)$ control for any heterogeneity due to unobservable characteristics in each geographically-based group and monthly time-effects are captured by $\theta_{t}$. The PVAR specification assumes that each cross-sectional group follows the same underlying structure, with fixed coefficients $\left(\Gamma_{1}\right.$ and $\left.\Gamma_{2}\right)$ for all different groups in the panel. The main benefit of this approach is that we can exploit the cross-sectional variation in house prices to improve the quality of our estimates, given the small sample size available for regional housing price indices at a monthly frequency. 


\section{Empirical Results}

In this section, we test the hypotheses described in Section』 First, we test the hypothesis on the conditional correlation between REIT and housing returns. Second, we test the hypothesis on short selling activity and house price predictability. Third, we test the hypothesis on the geographical cross-section of short selling activity and house price predictability.

\section{Conditional Correlations between REIT and Housing Returns}

A necessary condition for using REITs to hedge or speculate on house price fluctuations is that the returns of these two assets are correlated, such that investors can use the financial security (i.e. REITs) to capture movements in the real asset (i.e., house prices). However, the returns of the FHFA House Price Index exhibit a very low unconditional correlation with their matched REIT returns, equal to 0.04 in our sample. ${ }^{16}$ Thus, we begin our empirical analysis by testing to see if the correlation between REIT and housing returns is higher during market downturns.

Panel A of Table 4 displays the initial tests of Hypothesis 1. Column 1 shows the correlation between the FHFA housing returns $\left(R^{F H F A}\right)$ and CRSP-Ziman REIT market index returns $\left(R^{R E I T}\right)$ for the four geographical U.S. Census regions and for the aggregate U.S. market from February 1991 to December 2010. In columns (2) and (3), we calculate the conditional correlations in periods of housing market downturn (Bust periods) and no housing market downturn (No Bust periods); that is, cyclical counterparts to the "boom" and "average" periods of the housing market cycle. Periods of housing market downturns in a given region are defined as

\footnotetext{
${ }^{16}$ They also present a negative correlation with measures of short selling activity, REIT stock turnover, 10-year Treasury yield, and term spread. The online appendix to this paper presents the correlation structure among the main variables that we use in the empirical analyses.
} 
those months in which returns on the FHFA index are 1.64 standard deviations below the historical mean up to that particular month.

Two main results arise from this table. First, we find a positive and significant correlation between $R^{F H F A}$ and $R^{R E I T}$ in the full sample, equal to 0.075 . Second, this correlation varies significantly according to the state of the housing market. During periods of housing market downturns, we find a positive correlation for all regions except the Northeast. For example, the correlation equals 0.299 for All Regions in column (2). During non-downturn periods, the correlation is in fact negative and statistically significant for all regions except the Northeast, which is negative but not significant. This means that REITs returns tend to be below average when the FHFA housing index returns are above-average. In all cases, the difference between downturn (Bust) and no-downturn (No Bust) periods is statistically significant.

\section{[INSERT TABLE 4 HERE]}

Rather than displaying correlations, Panel B of Table 4 shows estimates for the regression specified in Eq. (4) for each U.S. Census region and for the pooled sample. We regress housing returns $\left(R^{F H F A}\right.$ ) on REIT returns ( $R^{R E I T}$ ), a dummy for the periods of housing downturn (Bust Dummy), and the interaction term $R^{R E I T} \times$ Bust Dummy. First, we find that the coefficient for $R^{R E I T}$ is negative and statistically significant in all cases. Second, the coefficient for $R^{R E I T} \times$ RE Bust Dummy is positive and significant in all cases, as Hypothesis 1 states. We find a larger and positive correlation between $R_{i, t}^{F H F A}$ and $R_{i, t}^{R E I T}$ during housing downturns (i.e., $R E$ Bust Dummy=1). The null hypothesis that the sum of $R^{R E I T} \times R E$ Bust Dummy and $R^{R E I T}$ coefficients is equal to zero is rejected in all cases. These results are equivalent to the ones that we provide in Panel A and support Hypothesis 1; that is, the correlations between REIT and housing returns are higher during economic downturns. 


\section{Short Selling Activity and House Price Predictability}

We examine the question of whether short selling activity can forecast the next month's house prices. Hypothesis 2, posits that higher levels of short selling activity predict lower house prices in the future. To test this hypothesis we use the panel VAR (PVAR) multivariate regressions described in Section 2. Before estimating the PVAR model, we use the panel unit root test developed by Choi (2001)) on each of the short selling variables to rule out nonstationarity. Results in Panel A of Table 5 reject the null hypothesis that the short sales measures contain a unit root 17

\section{[INSERT TABLE[5]HERE]}

We also test for the optimum number of lags to use in the PVAR. Panel B exhibits the lagselection analysis using On Loan as the measure of short selling. Results indicate that one lag is the optimal choice for the empirical analysis regardless of whether we use the Bayesian information criterion (BIC), Akaike's information criterion (AIC), or the Hannan-Quinn information criterion (HQIC). The results are similar for other short selling measures.

Table 6 displays the results of the PVAR models that we use to test Hypothesis 2. The panel is composed of three categories: Boom (No Boom) is defined as U.S. Census regions in which house prices had a cumulative run-up equal to or greater than (less than) $75 \%$ from January 2000 through December 2007 and Diversified is the the U.S. as a whole. We use the population-weighted FHFA House Price Index for each U.S. Census region to compute housing returns for Boom and No Boom, using the aggregate U.S. FHFA index for the Diversified category. We estimate specifications with three alternative measures of lagged short selling

\footnotetext{
${ }^{17}$ In unreported results we have also explored the existence of a cointegrating vector among house prices, REIT index levels, and equity lending variables, but cannot find any evidence to support this hypothesis.
} 
activity: (i) Utilization ${ }_{i, t-1}$; (ii) On $\operatorname{Loan}_{i, t-1}$, and (iii) Short Interest Ratio ${ }_{i, t-1}$. As further control variables, we use the lagged returns on the equal-weighted CRSP-Ziman aggregate index $(\operatorname{Lag} \operatorname{Ret}(R E I T))$ to account for the expectations about future prices embedded in REIT stock returns, the average bid-ask spreads (Bid-Ask Spread (\%)) and log turnover (Ln(Turnover)) to control for liquidity, and the term spread between short and long maturity Treasury bonds (Term Spread $(10 y-3 m))$. We compute stock market characteristics by equal-weighting data for all REITs with properties in a particular group. ${ }^{18}$ In columns (1)-(3), we find that all short selling measures can forecast housing prices in the following month. For example, the -0.064 coefficient estimate for utilization $(U)$ in column (3) means that a one standard deviation increase in utilization leads to a 0.074 standard deviation decrease in house price returns, supporting Hypothesis 2.

\section{[INSERT TABLE[6 HERE]}

A potential issue with the results in columns (1)-(3) is that they use data based on all REITs regardless of the property types that form their investments (e.g., residential, retail, office, healthcare, hotels, industrial, and self-storage), rather than just residential REITs, to forecast house prices. Thus, our results could be affected by REITs that are unrelated to housing assets but that are still included in the calculation of short sales measures. As a robustness test, the panel VARs shown in columns (4)-(6) (Residential-only REITs) compute short selling activity using only REITs that focus on residential real estate (i.e., those with the variable PTYPE 8 in the CRSP-Ziman dataset). About 5\% of REITs in our sample are classified as being residential only, meaning that the number of REITs with available short sales data in each region is small (i.e., it ranges from three to four per region). The inherent noise from such a small sample works against the power of our tests, but we expect our results to be unaltered because

\footnotetext{
${ }^{18}$ For Diversified we use REITs with properties spread out over different regions but with no combination of any two regions accounting for more than $50 \%$ of any REIT's portfolio
} 
variation in residential REIT financial variables, like returns and short sales activity, should be even more closely related to underlying housing prices. If investors want to hedge the risk of decreasing house prices by shorting REITs, then the average variation in the short selling intensity of residential REITs would be a stronger predictor than the average variation computed by using all types of REITs with investments in a particular region. This is exactly what we find, with results being very similar to those estimated in columns (1)-(3) but with lower standard errors. We also find that the ability of REIT returns $\left(R_{t}^{R E I T}\right)$ to forecast increases in real estate returns $\left(R_{t}^{R E}\right)$ is very weak in VARs. This means that REITs stocks incorporate information faster than house price indices and, more importantly, that measures of REIT short selling activity are better predictors of real estate returns than REITs stocks. These results show the importance of addressing the endogeneity issues among house prices, REIT returns, and short selling measures.

A majority of REITs make their investments in commercial rather than residential real estate. As an additional test of our hypothesis, we estimate a standard VAR in columns (7)-(9) using Apartments-only REITs rather than the panel VARs used in columns (1)-(6) that are based on the geographical location of REIT properties. We compute the short selling activity measures for Apartments-only REITs (i.e., those with $P T Y P E=8$ and $P S U B=2$ ) and determiner whether they can forecast the Moody's/RCA Commercial Property Price Index (CPPI) for apartments. The CPPI data are weighted, repeat-sales indices, which are computed using contemporaneous transaction-price-based data on private deals 19 The CPPI tracks specifically apartment properties, providing an alternative benchmark from which to track housing prices. In our sample, there is an average of 11.9 Apartments-only REITs. Results in column (9) show that all short selling measures can successfully forecast the apartments CPPI. For example, using utiliza-

\footnotetext{
${ }^{19}$ There are also specific CPPIs for commercial, industrial, office and the aggregate U.S. series, which are available at a monthly frequency. We use only data on apartments since the focus of our paper is on housing markets).
} 
tion $(U)$ as the measure of short selling activity yields a negative and significant coefficient of -0.018. We find equivalent results when using On Loan and Short Interest Ratio as measures of short selling activity. Overall, we can conclude that there is a negative relationship between short selling measures and future stock returns in line with Hypothesis 2.

Another useful output of VAR models is the ability to estimate the reaction of a particular endogenous variable to a shock in another endogenous variable. Because of the likely correlation among shocks to endogenous variables, we must make an identifying assumption to be able to orthogonalize the residuals. We use variables that appear earlier in the vector $z$ because, in the short-run, they are deemed "more exogenous" than latter ones, ${ }^{20}$

Figure 2 displays impulse-response graphs with the response of house price returns over twelve months, given a one standard deviation shock to alternative short sales proxies. We also report $95 \%$ bootstrapped confidence intervals based on 500 simulations. These results confirm the findings from our panel VAR analysis: a shock to short selling measures leads to a decrease in house price returns in the next month. For example, a one standard deviation shock to the short interest ratio is associated with a $-0.076 \%$ decrease in house prices the next month, which is equivalent to a 0.11 standard deviation change in house prices. These shocks are also very persistent, with lower returns still present even six months after the initial shock. The same standard deviation shock to short selling On Loan yields a similar change in house prices. In Panels A and C, we observe that the impact of shocks is statistically significant at least up to 10 months after the shock. Panel B (Short Interest Ratio) shows that the effect is statistically significant only in the first four months after the shock.

\section{[INSERT FIGURE2 2HERE]}

\footnotetext{
${ }^{20}$ Our results are unaffected by the ordering in which variables enter the system.
} 
We also perform a variance decomposition analysis in Figure 3. Each panel shows the fraction of the FHFA index returns' residuals variance over a 12-month period that can be explained by exogenous shocks to each measure of short selling activity and to REIT returns

indices. For example, Panel A shows that $43.3 \%$ of the 12 -month residual variability in $R_{t}^{F H F A}$ can be explained by shocks to $O n$ Loan and only $4.7 \%$ are due to shocks to $R_{t}^{R E I T}$. The explained fraction of forecasting residuals' variance for Short Interest Ratio and Utilization is lower but still large (20\% and 39\%, respectively). This analysis highlights the usefulness of proxies for measures of REIT short selling to forecast changes in house prices above and beyond the information contained in the dynamics of REIT returns.

\section{[INSERT FIGURE 3 HERE]}

Overall, these results show that the three measures of short selling (i.e., Utilization, On Loan, and Short Interest Ratio) can forecast house prices. The findings highlight the advantages of using our proxies for short selling intensity computed from equity lending data. These results are strongly significant for the prediction of both the FHFA and the apartments CPPI . Overall, we find evidence that the returns of real assets (i.e., housing) can be predicted by the behavior of lagged characteristics of financial securities (i.e., short selling intensity of REITs), in line with Hypothesis 2.

\section{Geographical Cross-Section of Short Selling Activity and House Price Pre- dictability}

In this subsection we study the geographical cross-section of REIT short selling activity according to the physical location of REIT real estate assets. First, we investigate the predictability of housing returns, $R E_{t}^{R E}$, for the four main U.S. census regions: Northeast, Midwest, South, 
and West. Table 7 exhibits the results of this test using standard VARs for each U.S. Census Region, with 82 observations per region. We find that an increase in Utilization $(U)$ forecasts a statistically significant decrease in house prices (i.e., FHFA house price index returns) in the Midwest, South and West regions. It forecasts a negative non-significant decrease in the Northeast region. Similar results obtain when we use On Loan $(O L)$, but are somewhat weaker for the Short Interest Ratio (SIR). This outcome highlights the advantage of measuring short selling activity with data from the equity lending market rather than with the standard short interest data used in the literature. This table also shows that these measures of short selling activity present a positive and significant autocorrelation.

\section{[INSERT TABLE[7]HERE]}

Investors attempt to hedge or speculate on lower house prices by establishing short positions on REIT stocks. We therefore expect to find a stronger link between the short selling activity of REITs with properties located in areas with larger house price run-ups and future housing returns in those areas (Hypothesis 3). Using hand-collected data on REIT property holdings, we classify each REIT as belonging to one of the following regional categories $\left(D_{i}^{L O C}\right)$ : Boom, No Boom, and Diversified ${ }^{21}$ We then compute short selling activity for REITs with the majority of their properties in each of these three regions ${ }^{22}$ We use returns of the No Boom regions as our benchmark and estimate a panel regression of next-period housing returns in a particular area $i, R_{i, t}^{R E}$, as a function of measures of short selling intensity $(S S)$ for that particular area plus control variables $(x)$ and monthly fixed-effects. We adapt the main specification in equation (6) to test Hypothesis 3 by adding an interaction term between past short selling activity and

\footnotetext{
${ }^{21}$ REITs that invest in mortgages are not included in our tests.

${ }^{22}$ For Diversified REITs, we use returns of the nationwide aggregate US house price index as the dependent variable.
} 
location, $S S_{i, t-1} \cdot D_{i}^{L O C}$ :

$$
R_{i, t}^{R E}=\Gamma_{0}+\Gamma_{1} \cdot S S_{i, t-1}+\Gamma_{2} \cdot S S_{i, t-1} \cdot D_{i}^{L O C}+\Gamma_{3} \cdot D_{i}^{L O C}+\Gamma_{4} x_{t-1}+\epsilon_{i, t} .
$$

Table 8 displays the tests of Hypothesis 3 using this panel regression. In columns (1)-(3), we show results using data for all types of REITs (e.g., residential, hotels, offices, etc.) to construct short sales measures for each area. In columns (4)-(6), we use only those REITs investing in residential properties (i.e. with variable PTYPE in the CRSP-Ziman database being equal to 8), in a similar approach to the one used in Table 6. Because No Boom is our benchmark group for this analysis, we expect the vector of coefficients $\Gamma_{3}$ of the interaction between past short selling activity and location, $x_{i, t-1} \cdot D_{i}^{L O C}$, to be negative. ${ }^{23}$ We find that the impact of short selling activity on housing returns varies within our groups. While there is no explanatory power for the benchmark No Boom area (i.e., the SS Variable coefficient is not significant), we find negative and significant coefficients for the SS Variable * D(Boom) and SS Variable * D(Diversified). For example, from column (4), a one standard deviation increase in Utilization leads to a $0.23 \%(=-0.028 * 8.05 \%)$ decrease in FHFA House Price Index returns in the following month. This is economically significant and corresponds to a 0.32 standard deviation decrease in house price returns ${ }^{24}$ This result is one of the key contributions of our paper. It shows that an increase in Utilization of REITs forecasts declines in house prices in areas that experienced a housing boom, but not for those areas that did not present a housing boom. The predictive power of Utilization in column (6) for REITs with properties located in Boom areas is significantly stronger than the predictability for REITs with properties in No Boom areas.

\footnotetext{
${ }^{23}$ Our results hold when we move the beginning of a set of "bust" months (i.e., No Boom months) one or two months forward.

${ }^{24}$ The mean return of the FHFA index is $-0.11 \%$ with a standard deviation of $0.70 \%$.
} 


\section{[INSERT TABLE[8 HERE]}

Altogether, these results support our hypothesis that measures of short selling derived from residential REITs, in particular Utilization and Short Interest Ratio, can forecast future house prices. Furthermore, there is an important asymmetric component in this relationship, with house prices reacting differently depending on the areas in which the underlying properties of the REITs are located. As a result, we find consistent house price predictability in line with our hypothesis for REITs with properties located in areas that had experienced a housing boom prior to our sample period.

\section{Trading Strategy}

Finally, we study the implementation of a trading strategy to hedge against house prices decreases, or to speculate on their fall, that arises from our previous analysis. Hypothesis 2 predicts that an increase in REITs' short selling activity forecasts a reduction in next month's housing returns. The trading strategy goes as follows: An investor who is long in housing should short REITs with properties located in the same region when she observes that the short selling activity of REITs is above a certain threshold relative to its historical mean. In practical terms, we create an indicator variable, D(High SS Variable), equal to 1 if the short selling activity of diversified U.S. REITs is at least 1.64 standard deviations above its historical mean, and equal to 0 otherwise $\sqrt{25}$ To facilitate the implementation of the strategy and use the same entry and exit points across all regions, we compute this indicator variable using the diversified REITs defined in Section 4.

Table 9 shows that the D(High SS Variable) variable can forecast next month's FHFA ag-

\footnotetext{
${ }^{25}$ Results are also robust to using two standard deviations above the mean. Notice that 1.64 standard deviation times above its mean is equivalent to the 95 percentile of the distribution.
} 
gregate housing prices, for both proxies for short selling intensity computed from REIT's stock lending data. Column [1] shows that whenever the measure of short selling Utilization, $U_{t}$, is 1.64 standard deviation times above its mean, then FHFA returns decrease an overage of $0.385 \%$ in the subsequent month. In column [2] this coefficient is also negative and significant when using On Loan $\left(O L_{t}\right)$. In columns [3]-[4], we also find similar results when using a 12-month rolling window to compute the dummy and avoid look-ahead biases. Since On Loan is the most reliable and quickest to obtain measure of short selling activity, let us focus on the result that arises from column [4]: when On Loan is 1.64 standard deviations above its mean using a 12-month rolling window, then FHFA returns decrease an average of $0.607 \%$ in the next month.

\section{[INSERT TABLE 9 HERE]}

While the results above show that short sales intensity can forecast prices in the subsequent month, investors are unable to directly short the FHFA index. Instead, we examine the performance of a trading strategy that is long the FHFA housing index, but that also incorporates a short position in REITs. The example provides evidence that we can successfully use REITs to hedge against housing price declines to improve investors returns during the 2006-2013 period.

Figure 4 exhibits the performance of a trading strategy that is long the FHFA House Price Index but uses REITs to short 50\% value of the long position whenever the D(High SS Variable) indicator variable, measured using On Loan, is equal to one. All the plots show the out-ofsample performance of the hedging strategy (dashed line) compared to the FHFA House Price Index (solid line). They are all normalized to \$100 in June 2007. Panel A shows the performance of the hedging strategy using individual U.S. Census FHFA Housing Price Indices on the long leg and using region-specific REITs on the short side of the strategy. These results show the success of the hedging ability of this strategy in regions that experienced large house price runups during the years prior to 2007, i.e., Northeast and West. Its performance is satisfactory 
for the South and absent for the Midwest, where we observed a smaller house price run-up in the same period. Panel B shows similar results when we examine the performance using diversified REIT to hedge against price decreases in the aggregate FHFA index. We obtain similar results when we use Utilization as a measure of short selling intensity. For example, the excess performance of the hedging strategy with respect to the respective FHFA index using Utilization is $20.1 \%$ and $7.6 \%$ in the Northeast and West, respectively. The equivalent excess performance when using On Loan are 28.6\% and 17.8\% (see Figure 4). For the aggregate U.S. Housing Price Index, the excess performance is $1.9 \%$ for Utilization and 9.3\%.for On Loan. This example reinforces the usefulness of using short selling intensity to hedge against housing price decreases.

We note that this strategy is unlikely to be used by retail investors given the cost of short selling, which include not only equity lending costs but also collateral and margin requirements. While the equity lending costs are not large, short sellers face collateral and margin requirements that can make the strategy unfeasible for retail investors. For instance, under Regulation $\mathrm{T}$, the Federal Reserve Board requires that short sales accounts have at least $150 \%$ of the value of the short sale at the beginning of the trade.

\section{[INSERT FIGURE 4/HERE]}

\section{Conclusion}

This paper investigates ways in which investors can use financial securities to bet on price decreases of real assets that face high transaction costs and short sales constraints. More specifically, we study the way in which Real Estate Investment Trusts (REITs) can be used to hedge the downside risk of housing markets or speculate on the decrease of house prices. 
We construct a dataset of REIT equity lending activity and FHFA index returns, both presented monthly between July 2006 through July 2013. We use the link between U.S. house prices and REITs with a panel VAR (PVAR) approach to test whether short selling activity has forecasting ability to explain the next month's house prices, taking into account the variation among housing cycles and across geographical areas. Our main findings are as follows. First, the correlation between REIT returns and FHFA housing returns is significantly positive only during housing downturns. Second, an increase in short selling activity forecasts decreases in house prices in the following month. Third, this negative correlation is greater in areas that have just experienced a housing boom than in those without a boom. We find that a one standard deviation increase in the fraction of shares on loan of REITs with properties in housing boom areas (e.g., the West region in the U.S.) forecasts a $0.52 \%$ (0.74 standard deviations) decrease in house prices in the following month. We do not find any effect in REITs with properties no housing boom areas (e.g., the Midwest region in the U.S.) Our results account for simultaneous determination and area-level heterogeneity between short selling activity, REITs stock returns, and house prices. We also implement a hedging strategy based on short selling intensity of REITs to reduce the downside of housing price decreases, showing that investors can limit potential losses by short selling REITs.

These results show the usefulness of financial data in forecasting changes in real asset prices and how specific geographical areas were affected differently by short selling activity during the financial crisis in 2008-2009. In particular, the demand for shorting REITs captured by the fraction of market capitalization on loan can help to forecast future house prices, with an important asymmetric component depending on the location of the underlying properties of the REITs. Short selling can be a useful tool for market participants to hedge against future price decreases. Regulators can track measures from the equity lending market to improve forecasts of house prices and implement policies to prevent real estate bubbles. Furthermore, imposing 
short selling constraints on stocks like REITs - which invest in assets subject to high transaction costs - matters for price efficiency and the dissemination of information. 


\section{Acknowledgements}

We thank Tom Davidoff, Thierry Foucault, Paolo Fulghieri, Nicolae Garleanu, David Geltner, Dwight Jaffee, Pedro Matos, Marc Lipson, Tano Santos, Todd Sinai, Richard Stanton, Eva Steiner, Michela Verardo, Nancy Wallace, Pierre-Olivier Weill, and the participants at the ASSA/AREUEA Meetings and the AEFIN Finance Forum for their helpful discussions and suggestions. We are grateful to Filipa Figueiredo and Elie El Khoury for excellent research assistantship. We are thankful to Real Capital Analytics for providing us with the Commercial Property Price Index (CPPI) data. We also thank Inessa Love for making the panel VAR routines used in Love and Zicchino (2006) available to researchers. Saffi acknowledges the financial support provided by the Cambridge Endownment for Research in Finance (CERF) and Vergara-Alert the support of the Public-Private Sector Research Center at IESE, the Spanish Ministry of Economy and Competitiveness (Ref. ECO2015-63711-P), and AGAUR (Project ref: 2014-SGR-1496). 


\section{References}

Abrigo, M. R., and I. Love. 2016. Estimation of Panel Vector Autoregression in Stata: a Package of Programs. Working Paper, University of Hawaii at Manoa, Department of Economics.

Ang, A., G. Bekaert, and M. Wei. 2007. Do Macro Variables, Asset markets, or Surveys Forecast Inflation Better? Journal of Monetary Economics 54:1163-1212.

Arnold, T., A. Butler, T. Crack, and Y. Zhang. 2005. The Information Content of Short Interest: A Natural Experiment. Journal of Business 78:1307-1336.

Asquith, P., and L. Meulbroek. 1995. An Empirical Investigation of Short Interest. Working Paper, Harvard Business School.

Bailey, W., and K. C. Chan. 1993. Macroeconomic Influences and the Variability of the Commodity Futures Basis. Journal of Finance 48:555-573.

Barkham, R., and D. Geltner. 1995. Price Discovery in American and British Property Markets. Real Estate Economics 23:21-44.

Benjamin, J., S. Sirmans, and E. Zietz. 2001. Returns and Risk on Real Estate and Other Investments: More Evidence. Journal of Real Estate Portfolio Management 7:183-214.

Blau, B., M. Hill, and H. Wang. 2011. REIT Short Sales and Return Predictability. Journal of Real Estate Finance and Economics 42:481-503.

Boehme, R., B. R. Danielsen, and S. M. Sorescu. 2006. Short-sale Constraints, Dispersion of Opinion and Overvaluation. Journal of Financial and Quantitative Analysis 41:455-487.

Boehmer, E., Z. R. Huszár, and B. D. Jordan. 2010. The Good News in Short Interest. Journal of Financial Economics 96:80-97.

Boudry, W. I., N. E. Coulson, J. G. Kallberg, and C. H. Liu. 2012. On the Hybrid Nature of REITs. Journal of Real Estate Finance and Economics 44:230-249.

Campbell, S. D., M. A. Davis, J. Gallin, and R. F. Martin. 2009. What Moves Housing Mar- 
kets: A Variance Decomposition of the Rent-Price Ratio. Journal of Urban Economics 66:90-102.

Chen, H., D. Downs, and G. Patterson. 2012. The Information Content of REIT Short Interest: Investment Focus and Heterogeneous Beliefs. Real Estate Economics 40:249-283.

Chen, H., and V. Singal. 2003. Role of Speculative Short Sales in Price Formation: the Case of the Weekend Effect. Journal of Finance 58:685-706.

Choi, I. 2001. Unit Root Tests for Panel Data. Journal of International Money and Finance 20:249-272.

Christoffersen, S. E. K., C. C. Geczy, and D. K. Musto. 2005. Crossborder Dividend Taxation and the Preference of Taxable and Non-taxable Investors: Evidence from Canada. Journal of Financial Economics 78:121-144.

Clayton, J., and G. MacKinnon. 2001. The Time-varying Nature of the Link Between REIT, Real Estate and Financial Asset Returns. Journal of Real Estate Portfolio Management $7: 43-54$.

Cohen, L., K. B. Diether, and C. J. Malloy. 2007. Supply and Demand Shifts in the Shorting Market. Journal of Finance 62:2061-2096.

Corradin, S., J. Fillat, and C. Vergara-Alert. 2014. Optimal Portfolio Choice with Predictability in House Prices and Transaction Costs. Review of Financial Studies 27:823-880.

Dechow, P., A. Hutton, L. Meulbroek, and R. Sloan. 2001. Short-sellers, Fundamental Analysis, and Stock Returns. Journal of Financial Economics 61:77-106.

Desai, H., K. Ramesh, S. Thiagarajan, and B. Balachandran. 2002. An Investigation of the Informational Role of Short Interest in the Nasdaq Market. Journal of Finance 57:22632287.

Geltner, D. 1998. How Accurate is the NCREIF Index as a Benchmark, and Who Cares? Real Estate Finance 14:25-37. 
Geltner, D., N. G. Miller, J. Clayton, and P. Eichholtz. 2001. Commercial Real Estate Analysis and Investments, vol. 1. Cincinnati, OH: South-Western.

Ghysels, E., A. Plazzi, W. N. Torous, and R. I. Valkanov. 2012. Forecasting Real Estate Prices. Handbook of Economic Forecasting 2.

Green, R. K. 1997. Follow the Leader: How Changes in Residential and Non-Residential Investment Predict Changes in GDP. Real Estate Economics 25:253-270.

Gyourko, J. 2009. Understanding Commercial Real Estate: How Different from Housing Is It? Journal of Portfolio Management 35:23-37.

Gyourko, J., and D. B. Keim. 1992. What Does the Stock Market Tell Us about Real Estate Returns? Real Estate Economics 20:457-485.

Hoesli, M., and E. Oikarinen. 2012. Are REITs Real Estate? Evidence from International Sector Level Data. Journal of International Money and Finance 31:1823-1850.

Holtz-Eakin, D., W. Newey, and H. S. Rosen. 1988. Estimating Vector Autoregressions with Panel Data. Econometrica 56:1371-95.

Huszár, Z. R., R. S. Tan, and W. Zhang. 2017. Do Short Sellers Exploit Industry Information? Journal of Empirical Finance 41:118-139.

Jones, C. M., and O. A. Lamont. 2002. Short-sale Constraints and Stock Returns. Journal of Financial Economics 66:207-239.

Koijen, R. S., O. Van Hemert, and S. Van Nieuwerburgh. 2009. Mortgage Timing. Journal of Financial Economics 93:292-324.

Kyle, A. 1985. Continuous Auctions and Insider Trading. Econometrica 53:1315-1335.

Lee, M.-L., M.-T. Lee, and K. C. Chiang. 2008. Real Estate Risk Exposure of Equity Real Estate Investment Trusts. Journal of Real Estate Finance and Economics 36:165.

Lewis, M. 2010. The Big Short: Inside the Doomsday Machine. New York, NY : W. W. Norton \& Company. 
Li, D. D., and K. Yung. 2004. Short Interest in Real Estate Investment Trusts. International Real Estate Review 7:56-70.

Liew, J., and M. Vassalou. 2000. Can Book-to-Market, Size and Momentum Be Risk Factors that Predict Economic Growth? Journal of Financial Economics 57:221-245.

Love, I., and L. Zicchino. 2006. Financial Development and Dynamic Investment Behavior: Evidence from Panel VAR. The Quarterly Review of Economics and Finance 46:190-210. Morawski, J., H. Rehkugler, and R. Füss. 2008. The Nature of Listed Real Estate Companies: Property or Equity Market? Financial Markets and Portfolio Management 22:101.

Nagel, S. 2005. Short Sales, Institutional Investors and the Cross-section of Stock Returns. Journal of Financial Economics 78:277-309.

Naranjo, A., and D. C. Ling. 1997. Economic Risk Factors and Commercial Real Estate Returns. Journal of Real Estate Finance and Economics 14:283-307.

Oikarinen, E., M. Hoesli, and C. Serrano. 2011. The Long-run Dynamics between Direct and Securitized Real Estate. Journal of Real Estate Research 33:73-103.

Pagliari, J. L., K. A. Scherer, and R. T. Monopoli. 2005. Public Versus Private Real Estate Equities: A More Refined, Long-term Comparison. Real Estate Economics 33:147-187.

Pesaran, M. H., and R. Smith. 1995. Estimating Long-run Relationships from Dynamic Heterogeneous Panels. Journal of Econometrics 68:79-113.

Porras Prado, M., P. A. C. Saffi, and J. Sturgess. 2016. Ownership Structure, Limits to Arbitrage, and Stock Returns: Evidence from Equity Lending Markets. Review of Financial Studies 29:3211-3244.

Quan, D. C., and S. Titman. 1999. Do Real Estate Prices and Stock Prices Move Together? An International Analysis. Real Estate Economics 27:183-207.

Rapach, D. E., M. C. Ringgenberg, and G. Zhou. 2016. Short Interest and Aggregate Stock Returns. Journal of Financial Economics 121:46-65. 
Riddiough, T. J., M. Moriarty, and P. Yeatman. 2005. Privately Versus Publicly Held Asset Investment Performance. Real Estate Economics 33:121-146.

Saffi, P. A. C., and K. Sigurdsson. 2011. Price Efficiency and Short Selling. Review of Financial Studies 24:821-852.

Spiegel, M. 2001. Housing Return and Construction Cycles. Real Estate Economics 29:521551.

Sun, J., X. Yang, and X. Zhao. 2012. Understanding Commercial Real Estate Indices. Journal of Real Estate Portfolio Management 18:289-303.

Yunus, N., J. A. Hansz, and P. J. Kennedy. 2012. Dynamic Interactions Between Private and Public Real Estate Markets: Some International Evidence. Journal of Real Estate Finance and Economics 45:1021-1040. 


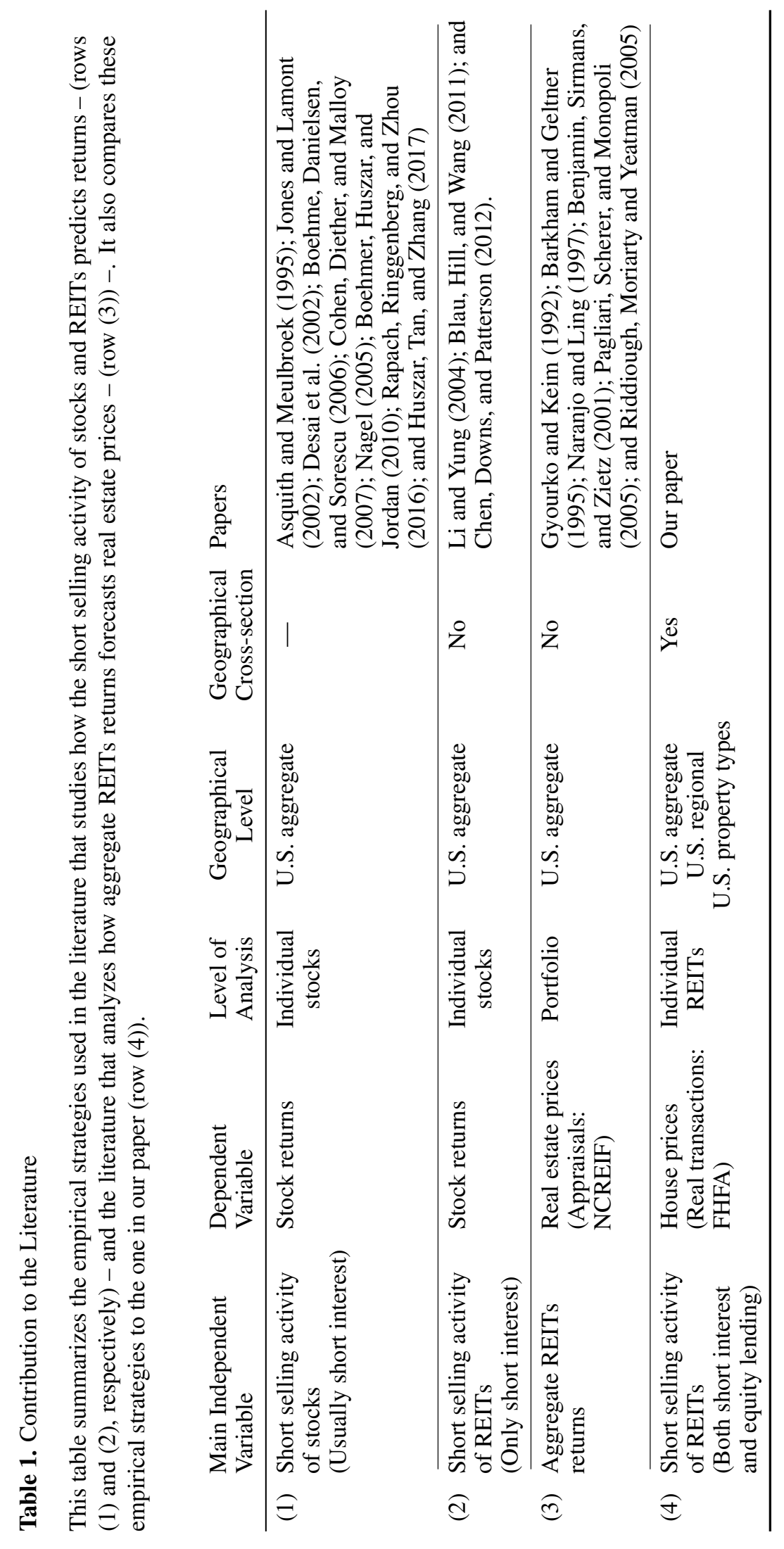


Table 2. Descriptive Statistics

This table shows descriptive statistics of monthly data from July 2006 through July 2013. Market Cap is the average REIT size in the sample in millions of US dollars. Ret(Individual REIT) is the average monthly return of individual REITs. Avg. Bid-Ask Spread is the average bid-ask spread at the close of the market. Avg. Daily Turnover is the average daily turnover as a fraction of market capitalization. Supply is the value of stocks available to borrow, scaled by market capitalization. On Loan is the value of shares lent out, scaled by market capitalization. Short Interest Ratio is defined as the value of shorted shares reported in Compustat ,scaled by market capitalization. Utilization is On Loan divided by Supply. $R^{F H F A}$ is the monthly change in the FHFA Index. $R^{C P P I}$ is the monthly change in the apartments CPPI. $R^{R E I T}$ is the mean return of the CRSP-Ziman REIT Index. Finally, 10y T-bond Yield is the constant maturity yield of Treasury bonds and Term Spread is the difference between the 10-year and the 3-month T-Bond yields.

\begin{tabular}{lcccccccc} 
Variable & Obs. & Mean & Median & Std.Dev. & Min. & Max. & Skewness & Kurtosis \\
\hline Number of REITs & 84 & 114.13 & 113.00 & 7.65 & 103.00 & 138.00 & 1.48 & 5.26 \\
Market Cap (USD mil.) & 84 & 5,128 & 3,560 & 4,034 & 778 & 19,489 & 1.40 & 4.47 \\
Ret(Individual REIT) & 84 & $0.99 \%$ & $1.50 \%$ & $7.86 \%$ & $-30.21 \%$ & $39.93 \%$ & 0.03 & 7.77 \\
Avg. Bid-Ask Spread (\%) & 84 & $0.14 \%$ & $0.09 \%$ & $0.14 \%$ & $0.03 \%$ & $1.14 \%$ & 2.84 & 14.19 \\
Avg. Daily Turnover & 84 & $0.28 \%$ & $0.23 \%$ & $0.15 \%$ & $0.09 \%$ & $1.04 \%$ & 1.84 & 7.10 \\
Supply (\%) & 84 & $29.00 \%$ & $30.28 \%$ & $6.58 \%$ & $13.35 \%$ & $40.44 \%$ & -0.73 & 2.79 \\
On Loan (\%) & 84 & $6.41 \%$ & $6.07 \%$ & $3.10 \%$ & $1.23 \%$ & $15.21 \%$ & 0.58 & 2.60 \\
Utilization (\%) & 84 & $18.62 \%$ & $17.57 \%$ & $8.05 \%$ & $5.23 \%$ & $44.17 \%$ & 0.41 & 2.41 \\
Short Interest Ratio (\%) & 84 & $3.25 \%$ & $2.85 \%$ & $1.89 \%$ & $0.15 \%$ & $10.64 \%$ & 1.15 & 4.15 \\
$R^{F H F A}$ & 84 & $-0.11 \%$ & $-0.03 \%$ & $0.70 \%$ & $-2.02 \%$ & $1.75 \%$ & -0.02 & 2.56 \\
$R^{C P P I}$ & 84 & $0.13 \%$ & $0.73 \%$ & $1.58 \%$ & $-4.22 \%$ & $3.07 \%$ & -1.17 & 3.48 \\
$R^{R E I T}$ & 84 & $0.64 \%$ & $1.10 \%$ & $7.82 \%$ & $-30.21 \%$ & $27.88 \%$ & -0.71 & 6.82 \\
IOy T-bond Yield & 84 & $3.22 \%$ & $3.32 \%$ & $1.01 \%$ & $1.51 \%$ & $5.03 \%$ & -0.02 & 1.92 \\
Term Spread $(10 y-3 m)$ & 84 & $1.98 \%$ & $2.15 \%$ & $1.22 \%$ & $-0.60 \%$ & $3.79 \%$ & -0.67 & 2.45 \\
\hline
\end{tabular}


Table 3. Short Selling Measures per Geographical Location of REITs Properties

This table shows the average and the standard deviation of short selling measures according to the geographical location of REITs properties using data from July 2006 through July 2013. Panel A shows these statistics for REITs in each U.S. Census region. If more than $50 \%$ of the properties of a REIT are located in one of the four U.S. Census regions, Northeast, Midwest, South, and West, then it is classified as being part of that specific region group. If there is no region containing more than $50 \%$ of the REIT's properties but the REIT has more than $50 \%$ of its properties in a combination of two regions, then we create a group for the specific combination of two regions. Only the pairs Northeast+South, Northeast+West, Midwest+South, and South+West have at least one REIT. In total, we have eight regional groups. If the REIT has properties spanning different regions but no combination of two regions accounting for more than 50\% of the REIT's properties, then the REIT is classified as Diversified. Panel B shows the summary statistics grouped by areas that have experienced a relative price boom in their housing markets (Housing Boom areas), defined as areas in which house prices had a cumulative run-up equal to or greater than 75\% during the January 2000 - December 2007 period, and areas that have not experienced such an increase (No Housing Boom areas). No. REITs is the number of REITs in each group. Supply is the value of stocks available to borrow, scaled by market capitalization. On Loan is the value of shares lent out, scaled by market capitalization. Short Interest Ratio (SIR) is defined as the value of shorted shares reported in Compustat, scaled by market capitalization. Utilization is On Loan divided by Supply.

Panel A. By U.S. Census Regions

\begin{tabular}{|c|c|c|c|c|c|c|}
\hline $\begin{array}{l}\text { Geographical Location } \\
\text { of the REITs Properties }\end{array}$ & & $\begin{array}{l}\text { No. } \\
\text { REITs }\end{array}$ & $\begin{array}{l}\text { Supply } \\
(\%)\end{array}$ & $\begin{array}{l}\text { On Loan } \\
(\%)\end{array}$ & $\begin{array}{l}\text { SIR } \\
(\%)\end{array}$ & $\begin{array}{l}\text { Utilization } \\
\quad(\%)\end{array}$ \\
\hline \multirow[t]{2}{*}{ Northeast (N) } & Mean & 4.04 & 35.29 & 8.08 & 2.27 & 18.74 \\
\hline & St.Dev. & 0.19 & 3.59 & 2.88 & 1.07 & 7.01 \\
\hline \multirow{2}{*}{ Midwest (M) } & Mean & 1.00 & 18.17 & 2.81 & 0.03 & 13.31 \\
\hline & St.Dev. & 0.00 & 3.58 & 1.28 & 0.27 & 6.91 \\
\hline \multirow[t]{2}{*}{ South (S) } & Mean & 13.24 & 29.31 & 7.42 & 3.49 & 22.59 \\
\hline & St.Dev. & 1.46 & 2.57 & 2.28 & 1.22 & 7.86 \\
\hline \multirow[t]{2}{*}{ West (W) } & Mean & 4.93 & 35.38 & 10.29 & 5.00 & 23.84 \\
\hline & St.Dev. & 0.40 & 3.52 & 4.28 & 3.21 & 9.48 \\
\hline \multirow{2}{*}{$\mathrm{N}+\mathrm{S}$} & Mean & 1.00 & 33.93 & 10.12 & 9.20 & 23.70 \\
\hline & St.Dev. & 0.00 & 4.96 & 6.81 & 4.96 & 14.89 \\
\hline \multirow[t]{2}{*}{$\mathrm{N}+\mathrm{W}$} & Mean & 2.06 & 31.32 & 4.31 & 0.92 & 11.71 \\
\hline & St.Dev. & 0.24 & 4.51 & 1.99 & 1.63 & 6.66 \\
\hline \multirow[t]{2}{*}{$\mathrm{M}+\mathrm{S}$} & Mean & 6.62 & 29.48 & 5.98 & 0.71 & 17.74 \\
\hline & St.Dev. & 0.79 & 2.98 & 2.02 & 0.36 & 5.79 \\
\hline \multirow[t]{2}{*}{$\mathrm{S}+\mathrm{W}$} & Mean & 11.27 & 29.47 & 5.23 & 3.70 & 15.62 \\
\hline & St.Dev. & 0.76 & 3.25 & 2.55 & 1.75 & 7.45 \\
\hline \multirow[t]{2}{*}{ Diversified } & Mean & 62.30 & 31.18 & 7.71 & 6.83 & 19.35 \\
\hline & St.Dev. & 5.63 & 3.80 & 2.56 & 2.32 & 5.15 \\
\hline \multicolumn{7}{|c|}{ Panel B. By Boom vs. No Boom } \\
\hline \multicolumn{2}{|l|}{$\begin{array}{l}\text { Geographical Location } \\
\text { of the REITs Properties }\end{array}$} & $\begin{array}{l}\text { No. } \\
\text { REITs }\end{array}$ & $\begin{array}{l}\text { Supply } \\
(\%)\end{array}$ & $\begin{array}{l}\text { On Loan } \\
(\%)\end{array}$ & $\begin{array}{l}\text { SIR } \\
(\%)\end{array}$ & $\begin{array}{l}\text { Utilization } \\
\quad(\%)\end{array}$ \\
\hline \multirow[t]{2}{*}{ No Housing Boom Areas } & Mean & 25.39 & 28.36 & 7.44 & 6.85 & 23.63 \\
\hline & St.Dev. & 2.30 & 3.16 & 1.98 & 1.83 & 5.68 \\
\hline \multirow[t]{2}{*}{ Housing Boom Areas } & Mean & 12.21 & 35.22 & 10.30 & 8.75 & 24.68 \\
\hline & St.Dev. & 0.87 & 3.60 & 2.93 & 3.08 & 6.53 \\
\hline \multirow[t]{2}{*}{ Diversified } & Mean & 62.30 & 31.18 & 7.71 & 6.83 & 19.35 \\
\hline & St.Dev. & 5.63 & 3.80 & 2.56 & 2.32 & 5.15 \\
\hline
\end{tabular}


Table 4. Test of Hypothesis 1. Conditional Correlations between REIT and Housing Returns

Panel A displays the correlation between the returns of the FHFA House Price Index, $R^{F H F A}$, and the returns of the aggregate portfolio of REITs, $R^{R E I T}$, according to the geographical location of the majority of REITs properties (i.e., the U.S. Census regions Northeast, Midwest, South, and West, and the U.S. Aggregate) and split by housing market cycles. Column (1) uses data from February 1991 through December 2013, column (2) includes periods of no downturns in the housing markets (i.e., No Bust periods), and column (3) only includes the periods of housing downturns (i.e., Bust periods). Bust periods are defined as months in which the FHFA House Price Index is 1.64 standard deviations below the rolling average from 1990 up through a given month. The remaining months are classified as No Bust Periods. Panel B displays, for each U.S. Census region and for the pooled sample, the results of regressing $R^{F H F A}$ on $R^{R E I T}$, an indicator variable (Bust Dummy) equal to one for Bust periods months, and the interaction term $R^{R E I T} \times$ Bust Dummy. Robust standard errors are reported in brackets. ${ }^{*},{ }^{* *}$, and ${ }^{* * *}$ denote significance at the $10 \%, 5 \%$, and $1 \%$ level, respectively.

\begin{tabular}{|c|c|c|c|}
\hline & $\begin{array}{c}\text { All periods } \\
\text { (Full sample) } \\
\text { (1) }\end{array}$ & $\begin{array}{l}\text { No bust } \\
\text { periods } \\
\text { (2) }\end{array}$ & $\begin{array}{l}\text { Bust } \\
\text { periods } \\
\text { (3) }\end{array}$ \\
\hline Northeast (N) & 0.0148 & $\overline{-0.0003}$ & 0.2996 \\
\hline Midwest (M) & 0.0184 & 0.0697 & 0.0830 \\
\hline South (S) & 0.0318 & -0.0497 & 0.0672 \\
\hline West (W) & 0.1307 & -0.1301 & 0.2172 \\
\hline All Regions & 0.0578 & -0.0356 & 0.2075 \\
\hline
\end{tabular}

\begin{tabular}{lccccccc}
\multicolumn{7}{l}{ Panel B. Conditional Regressions of $R^{F H F A}$ on $R^{R E I T}$ by Geographical Regions } \\
\hline \multirow{2}{*}{ Region } & $R^{R E I T}$ & Bust & $R^{R E I T} \times$ & Intercept & Adj. $R^{2}$ & Obs. \\
\cline { 3 - 7 } Northeast (N) & -0.0094 & 0.0004 & 0.0285 & $0.0030^{* * *}$ & 0.010 & 270 \\
& {$[0.0107]$} & {$[0.0010]$} & {$[0.0223]$} & {$[0.0006]$} & & \\
Midwest (M) & $-0.0268^{* * *}$ & -0.0005 & $0.0566^{* * *}$ & $0.0034^{* * *}$ & 0.066 & 270 \\
& {$[0.0102]$} & {$[0.0008]$} & {$[0.01912]$} & {$[0.0005]$} & & \\
South (S) & $-0.0295^{* * *}$ & -0.0001 & $0.0693^{* * *}$ & $0.0038^{* * *}$ & 0.086 & 270 \\
& {$[0.0078]$} & {$[0.0007]$} & {$[0.0191]$} & {$[0.0004]$} & & \\
West (W) & $-0.0313^{* * *}$ & -0.0009 & $0.1052^{* * *}$ & $0.0048^{* * *}$ & 0.087 & 270 \\
& {$[0.0116]$} & {$[0.0014]$} & {$[0.0209]$} & {$[0.0007]$} & & \\
All Regions & $-0.0243^{* * *}$ & -0.0003 & $0.0649^{* * *}$ & $0.0038^{* * *}$ & 0.051 & 1,080 \\
& {$[0.0052]$} & {$[0.0005]$} & {$[0.0110]$} & {$[0.0003]$} & & \\
\hline
\end{tabular}


Table 5. Panel Vector Autoregressions: Unit Root Tests and Lag Selection

Panel A presents panel data unit root tests of short selling measures activity using the Fischer-type test as in Choi (2001)). We use the following measures of short selling activity: On Loan, Short Interest Ratio, and Utilization. All tests are based on Augmented Dickey-Fuller using two lags, include a drift term, and subtract cross-section averages for each panel. We report test statistics and associated $p$-values for the null hypothesis that all panels contain a unit root for a particular variable. Panel B reports values for the Bayesian information criterion (BIC), Akaike's information criterion (AIC), and the Hannan-Quinn information criterion (HQIC) for up to four lags for the system comprised by $O n L o a n, R^{R E I T s}$, and $R^{F H F A}$.

\begin{tabular}{lcc}
\multicolumn{3}{c}{ Panel A. Panel Data Unit Root Test } \\
\hline \multicolumn{3}{c}{$\mathrm{H}_{0}:$ All panels contain unit root } \\
\hline Variable & Z-stat & p-value \\
\hline Utilization & -3.70 & 0.000 \\
On Loan & -2.64 & 0.004 \\
Short Interest Ratio & -3.36 & 0.000 \\
\hline Number of Panels (N) & 3 & \\
Number of Periods (T) & 85 & \\
\hline
\end{tabular}

Panel B. Information Criteria for Alternative Lags of On Loan

\begin{tabular}{cccc}
\hline Lag & BIC & AIC & $H Q I C$ \\
\hline 1 & -156.53 & -33.55 & -83.19 \\
2 & -123.38 & -31.14 & -68.37 \\
3 & -82.85 & -21.36 & -46.17 \\
4 & -42.32 & -11.57 & -23.98 \\
\hline
\end{tabular}




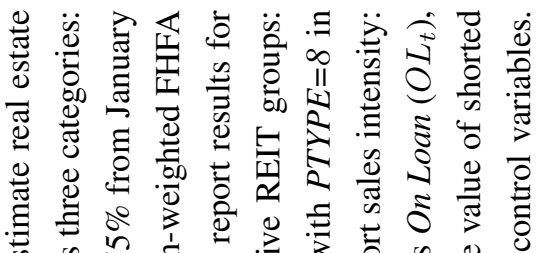

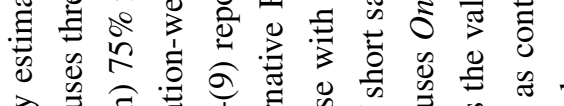

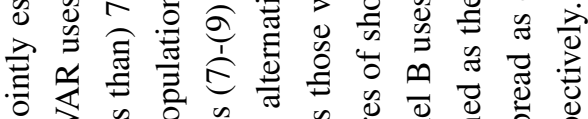

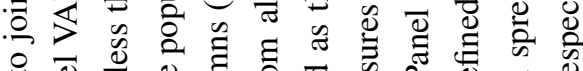

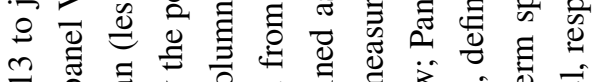

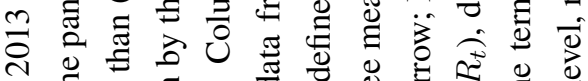

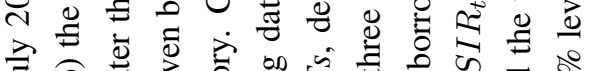

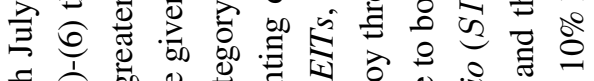

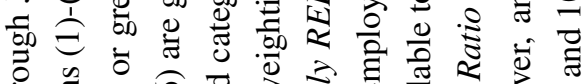

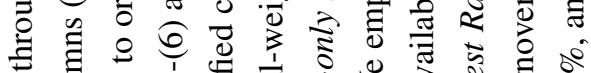

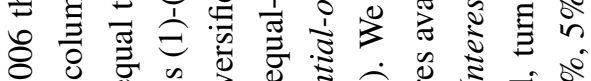

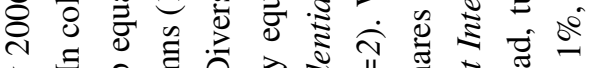

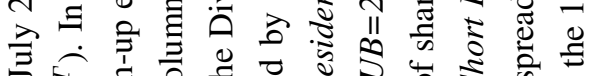
年

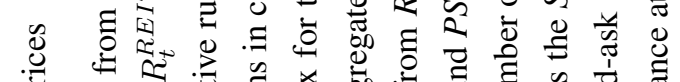

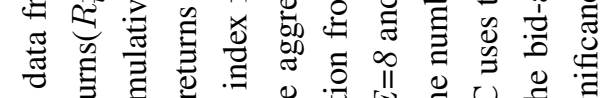

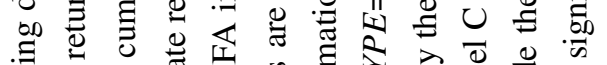
等

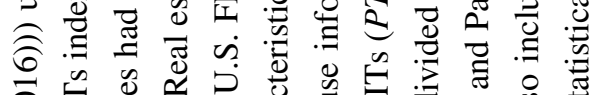

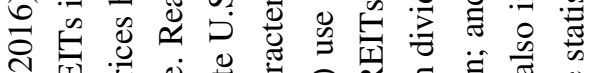

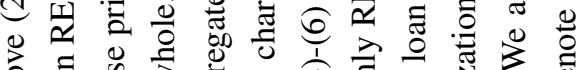

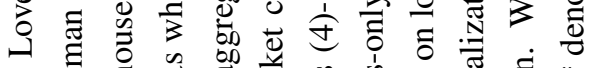

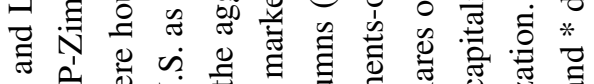

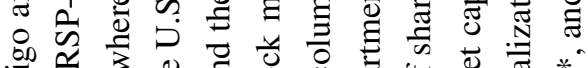

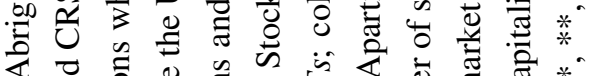

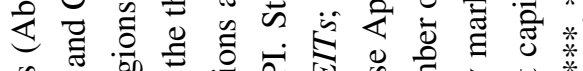

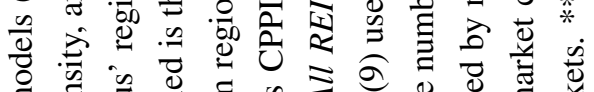
年 w (5)

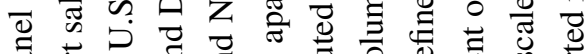
政

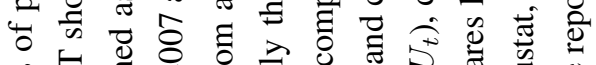
4

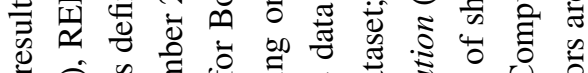

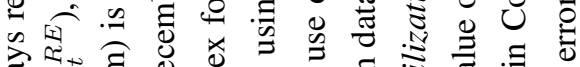

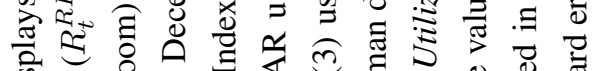

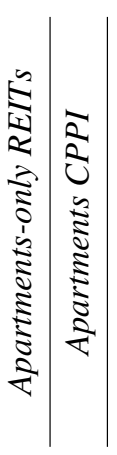

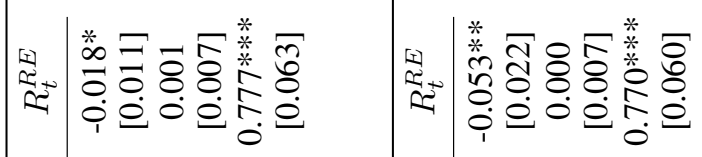

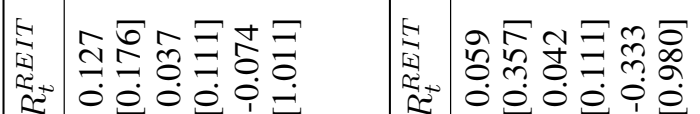

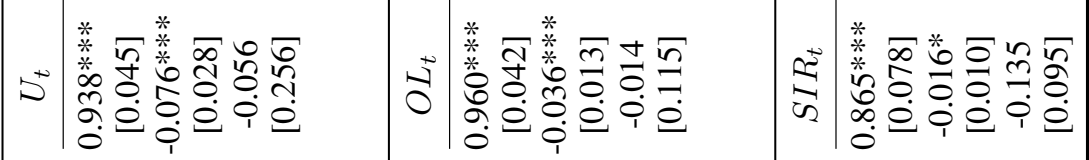

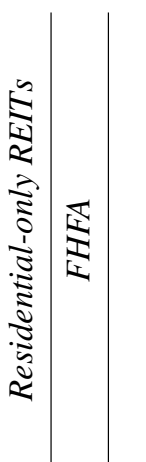

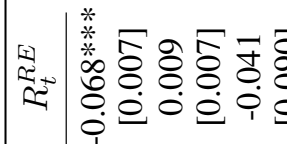

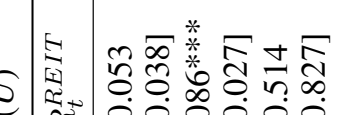

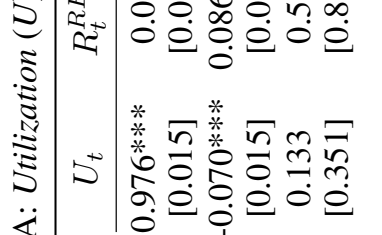

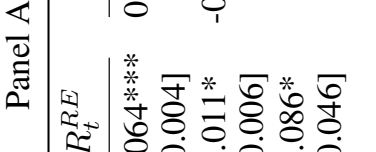

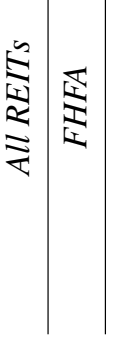
굴

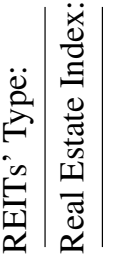

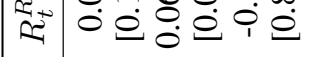

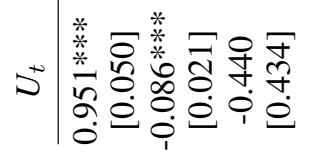

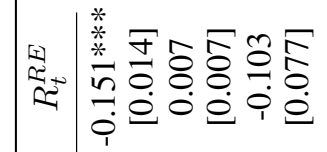

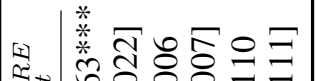
24:

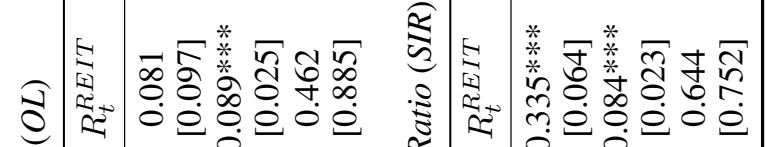
음

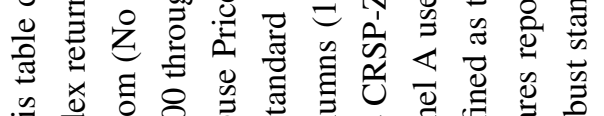

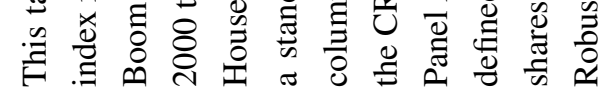




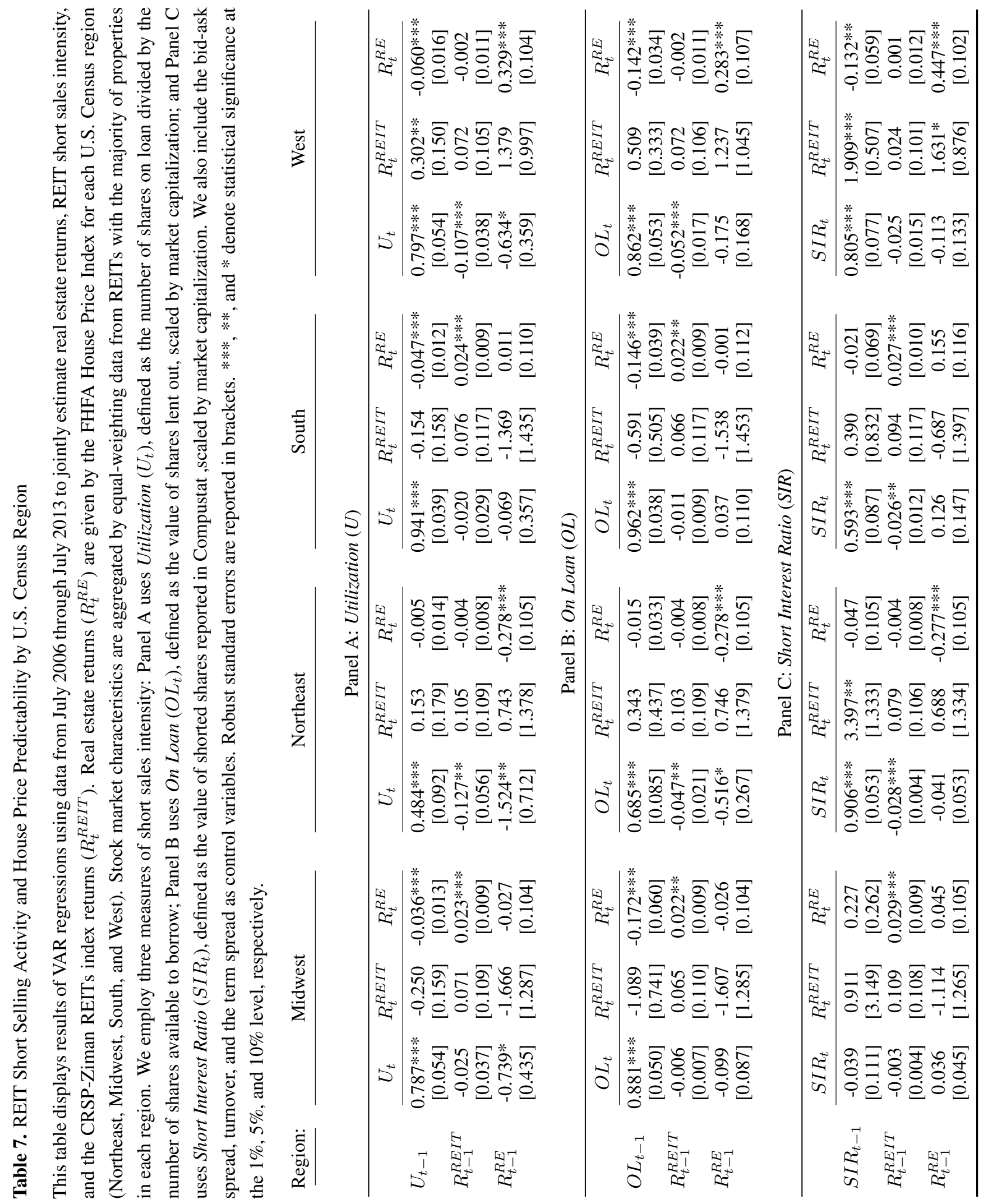




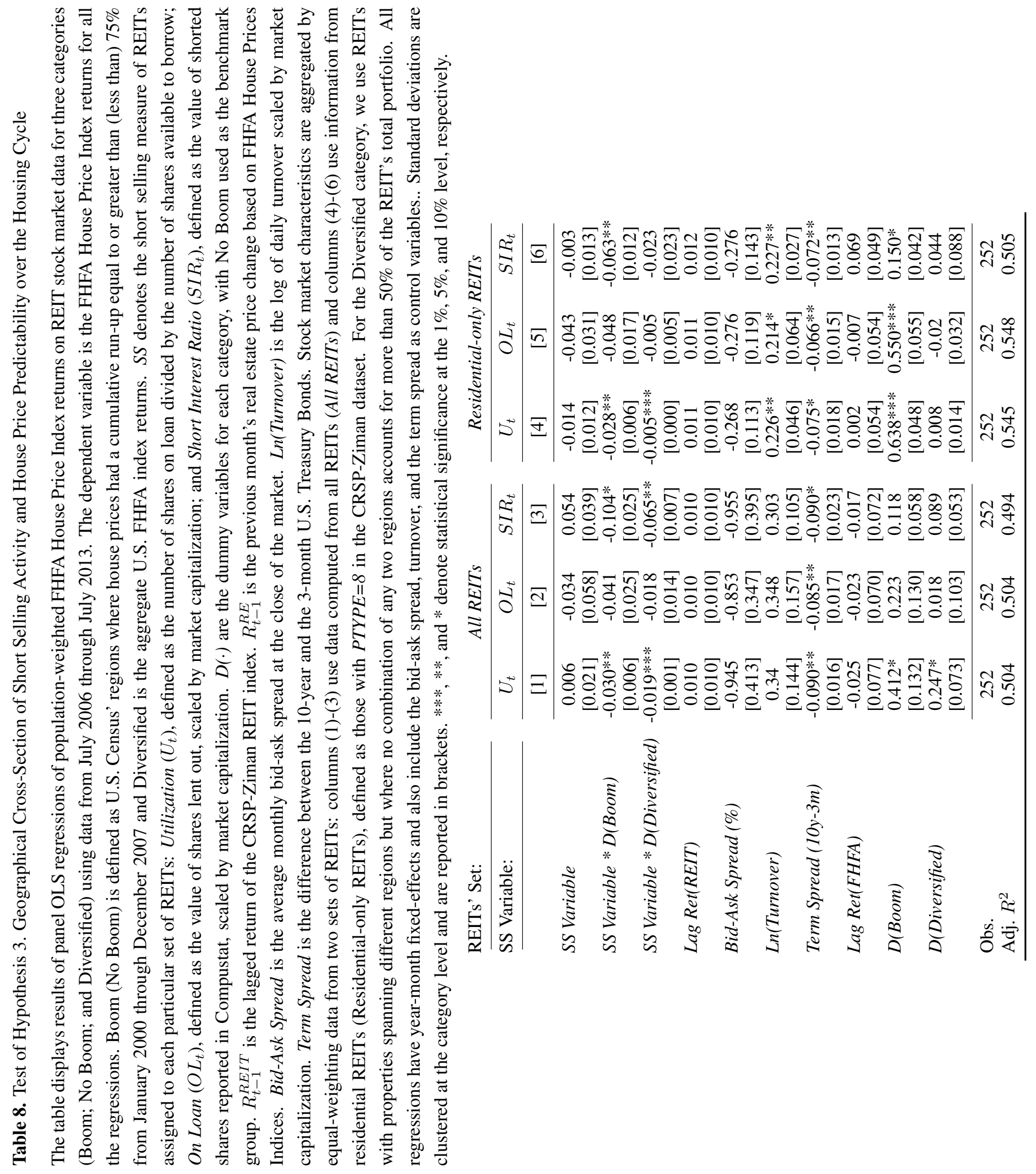


Table 9. Trading Strategy. Rationale and Efficiency

The table displays results of OLS regressions of the aggregate U.S. FHFA House Price Index next period's return on an indicator variable for high short selling intensity, D(High SS Variable), from July 2006 through July 2013. $D$ (High SS Variable) is an indicator variable equal to 1 if the short selling measure of diversified U.S. REITs' in a given month is 1.64 standard deviations above the sample mean (columns [1] and [2]) or above the previous 12-month's rolling-window mean (columns [3] and [4]). SS Variable denotes the short selling measure employed: Utilization $\left(U_{t}\right)$, defined as the number of shares on loan divided by the number of shares available to borrow; and $O n$ Loan $\left(O L_{t}\right)$, defined as the value of shares lent out, scaled by market capitalization. $R_{t-1}^{R E I T}$ is the lagged return of the CRSP-Ziman REIT index. Bid-Ask Spread is the average monthly bid-ask spread at the close of the market. Ln(Turnover) is the log of daily turnover scaled by market capitalization. All regressions include the bid-ask spread, turnover, and the term spread as control variables. Robust standard errors are reported in brackets. $* * *, * *$, and $*$ denote statistical significance at the $1 \%, 5 \%$, and $10 \%$ level, respectively.

\begin{tabular}{|c|c|c|c|c|}
\hline \multirow{2}{*}{$\begin{array}{l}\text { REITs' Set: } \\
\text { SS Variable: }\end{array}$} & \multicolumn{2}{|c|}{ All sample } & \multicolumn{2}{|c|}{ 12-month rolling window } \\
\hline & $U_{t}$ & $O L_{t}$ & $U_{t}$ & $O L_{t}$ \\
\hline & {$[1]$} & [2] & [3] & {$[4]$} \\
\hline$D$ (High SS Variable) & $\begin{array}{l}-0.385^{*} \\
{[0.222]}\end{array}$ & $\begin{array}{c}-0.424 * * * \\
{[0.148]}\end{array}$ & $\begin{array}{c}-0.540 * * * \\
{[0.188]}\end{array}$ & $\begin{array}{c}-0.607 * * * \\
{[0.203]}\end{array}$ \\
\hline Lag $\operatorname{Ret}(R E I T)$ & $\begin{array}{c}0.017^{*} \\
{[0.009]}\end{array}$ & $\begin{array}{c}0.013 \\
{[0.009]}\end{array}$ & $\begin{array}{c}0.011 \\
{[0.010]}\end{array}$ & $\begin{array}{c}0.010 \\
{[0.009]}\end{array}$ \\
\hline Bid-Ask Spread (\%) & $\begin{array}{l}-1.012 \\
{[0.614]}\end{array}$ & $\begin{array}{l}-1.049^{*} \\
{[0.580]}\end{array}$ & $\begin{array}{c}-2.030 * * * \\
{[0.662]}\end{array}$ & $\begin{array}{c}-1.608 * * \\
{[0.670]}\end{array}$ \\
\hline Ln(Turnover) & $\begin{array}{c}0.152 \\
{[0.172]}\end{array}$ & $\begin{array}{c}0.127 \\
{[0.157]}\end{array}$ & $\begin{array}{c}0.358^{*} \\
{[0.186]}\end{array}$ & $\begin{array}{c}0.285 \\
{[0.175]}\end{array}$ \\
\hline Term Spread (10y-3m) & $\begin{array}{l}-0.066 \\
{[0.049]}\end{array}$ & $\begin{array}{l}-0.062 \\
{[0.049]}\end{array}$ & $\begin{array}{c}-0.255^{* * *} * \\
{[0.092]}\end{array}$ & $\begin{array}{c}-0.291 * * * \\
{[0.104]}\end{array}$ \\
\hline Lag $\operatorname{Ret}(F H F A)$ & $\begin{array}{c}0.501 * * * \\
{[0.113]}\end{array}$ & $\begin{array}{c}0.458 * * * * \\
{[0.112]}\end{array}$ & $\begin{array}{c}0.417 * * * \\
{[0.126]}\end{array}$ & $\begin{array}{c}0.396 * * * \\
{[0.128]}\end{array}$ \\
\hline Obs. & 84 & 84 & 72 & 72 \\
\hline Adj. $R^{2}$ & 0.404 & 0.422 & 0.448 & 0.466 \\
\hline
\end{tabular}


Figure 1. REITs' Short Selling Activity, Housing Returns and the Geographical Location of REIT Properties

This figure plots measures of the average equity lending activity (Supply and On Loan) of REITs with more than $50 \%$ of their properties located in one of the U.S. Census regions (i.e., Northeast, Midwest, South, and West). We compare these measures to the FHFA House Price Index. Supply is the amount available to borrow, scaled by market capitalization. On Loan is the number of shares effectively lent out, scaled by total shares outstanding. The left side of the vertical axis shows the scale for the house price index $(1.0=$ January 2000). The right side of the vertical axis shows the scale for Supply and On Loan. Short selling measures are available only from July 2006 through July 2013.

Panel A. Geographical location by U.S. Census regions
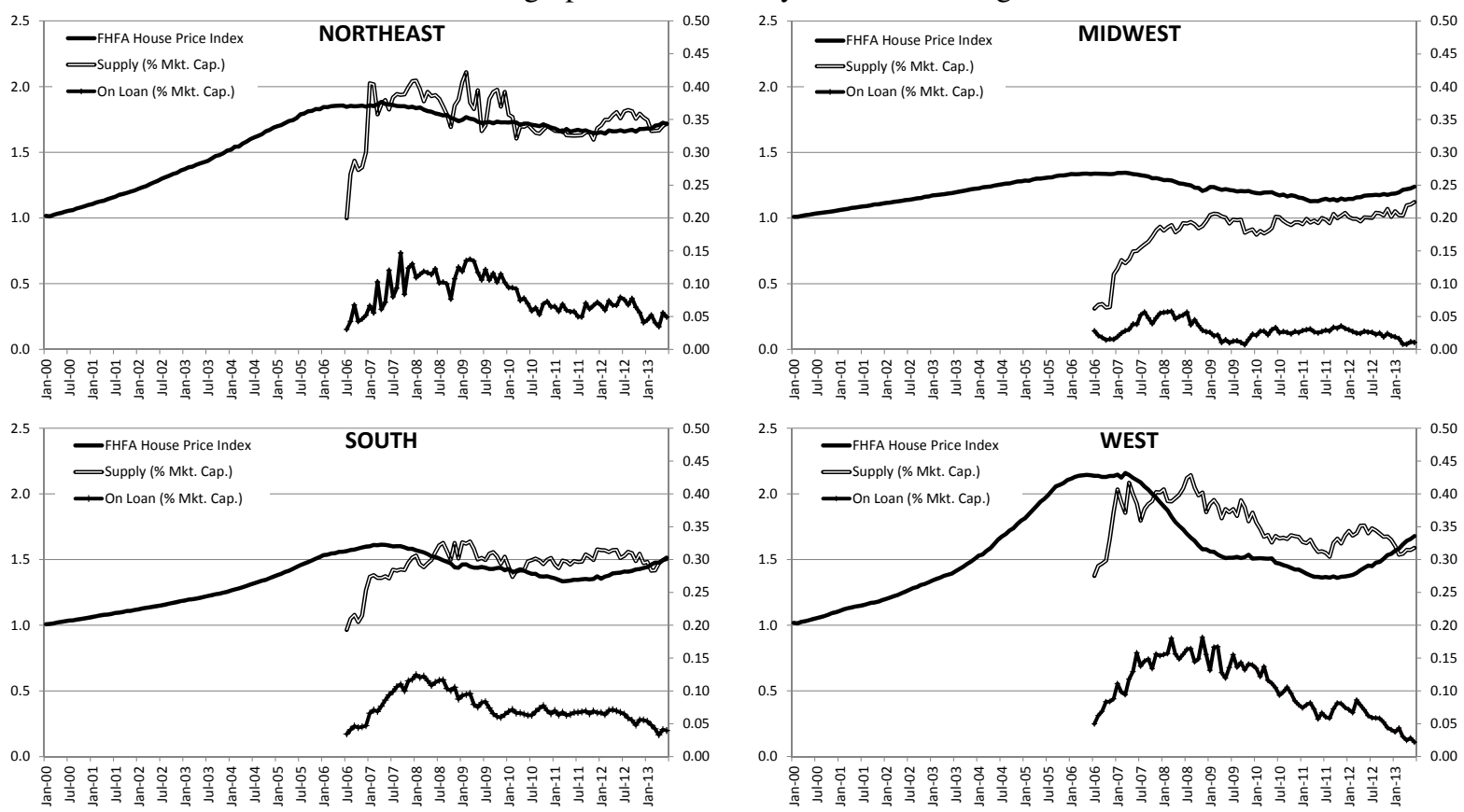

Panel B. Geographical Location by Areas that Experienced a Housing Boom or No Boom
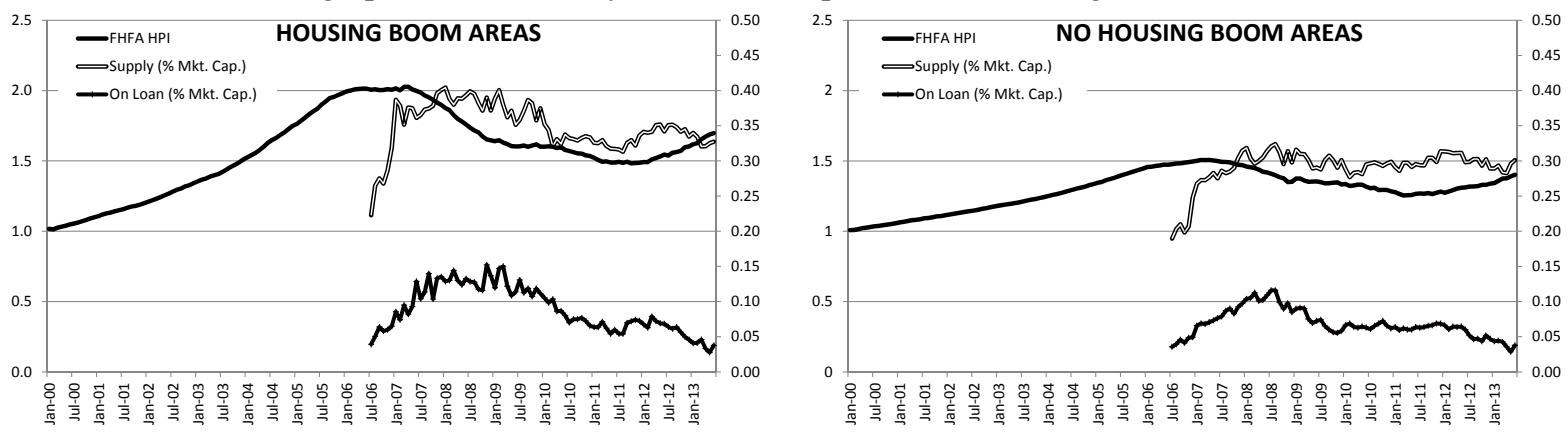
Figure 2. Impulse Response Functions of Housing Returns

The figure plots the values (in percentage points) of the impulse-response (IR) function for the panel VAR estimated in columns (1)-(3) of Table 6 given a one standard deviation shock to short selling measures. Each panel unit in the panel VAR corresponds to one of three categories: Boom (No Boom) is defined as U.S. Census regions in which house prices had a cumulative run-up equal to or greater than (less than) 75\% from January 2000 through December 2007, and Diversified is the the U.S. as whole. We consider three measures of short selling activity: Utilization is the number of shares on loan divided by the number of shares available to borrow (Panel A), On Loan is the number of shares effectively lent out, scaled by total shares outstanding (Panel B), and Short Interest Ratio is the value of shorted shares reported in Compustat, scaled by market capitalization (Panel C). We use the population-weighted FHFA House Price Index for each region as a measure of house prices to compute housing returns for Boom and No Boom; For the Diversified category we use the aggregate U.S. FHFA index. Dotted red lines correspond to $5 \%$ and $95 \%$ confidence intervals calculated over 500 bootstrapped simulations.
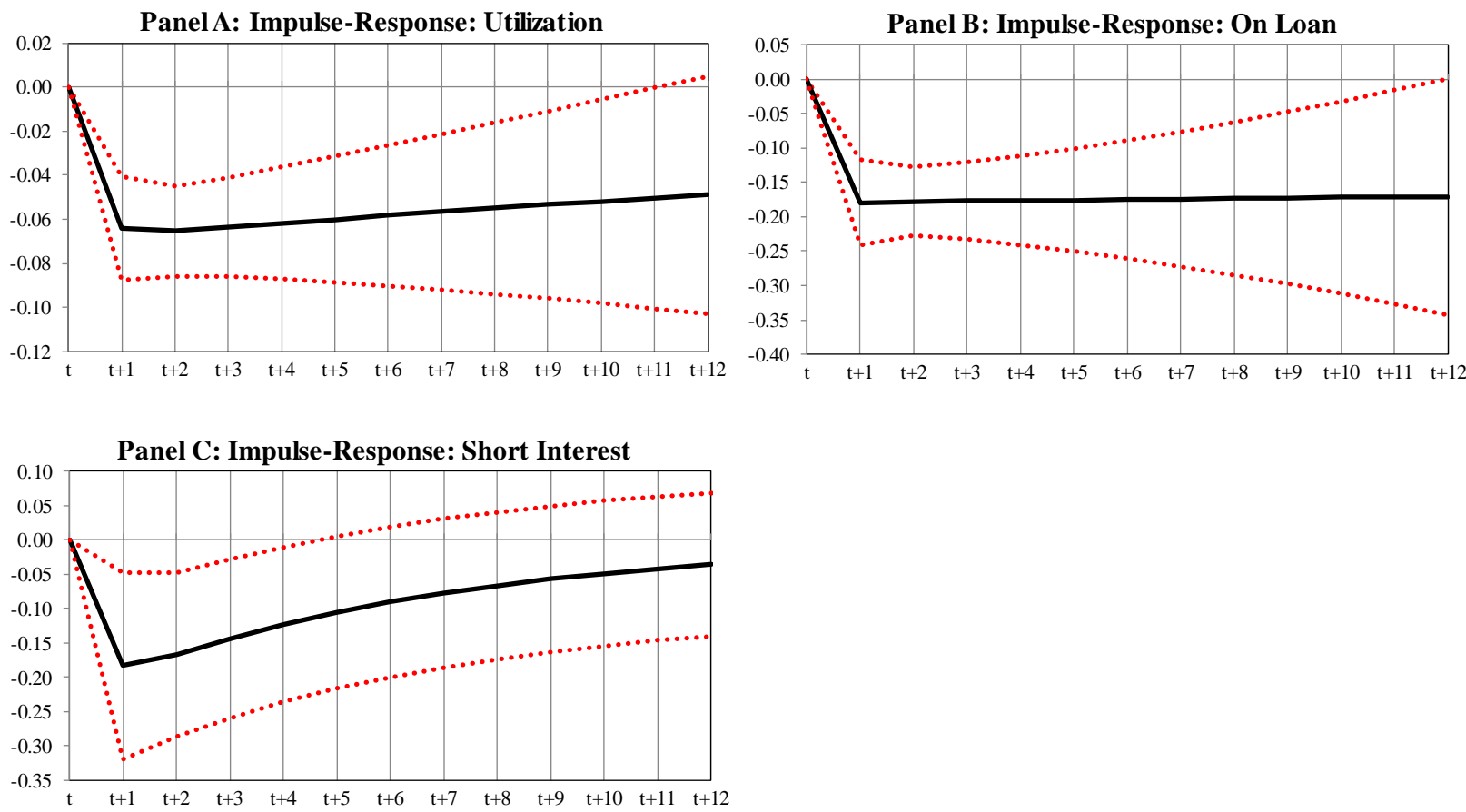
Figure 3. Variance Decomposition

This figure shows variance decompositions of the housing returns following shocks to short selling measure and Ret(REITs) based on the panel VAR estimated in columns (1)-(3) of Table 6 Each panel unit in the panel VAR corresponds to one of three categories: Boom (No Boom) is defined as U.S. Census regions in which house prices had a cumulative run-up equal to or greater than (less than) 75\% from January 2000 through December 2007, and Diversified is the the U.S. as a whole. We consider three measures of short selling activity: Utilization is the number of shares on loan divided by the number of shares available to borrow (Panel A); On Loan is the number of shares effectively lent out, scaled by total shares outstanding (Panel B); and Short Interest Ratio is the value of shorted shares reported in Compustat scaled by market capitalization (Panel C). We use the population-weighted FHFA House Price Index for each region as a measure of house prices to compute housing returns for Boom and No Boom. For the Diversified category we use the aggregate U.S. FHFA index. Dotted red lines correspond to 5\% and $95 \%$ confidence intervals calculated over 500 bootstrapped simulations.
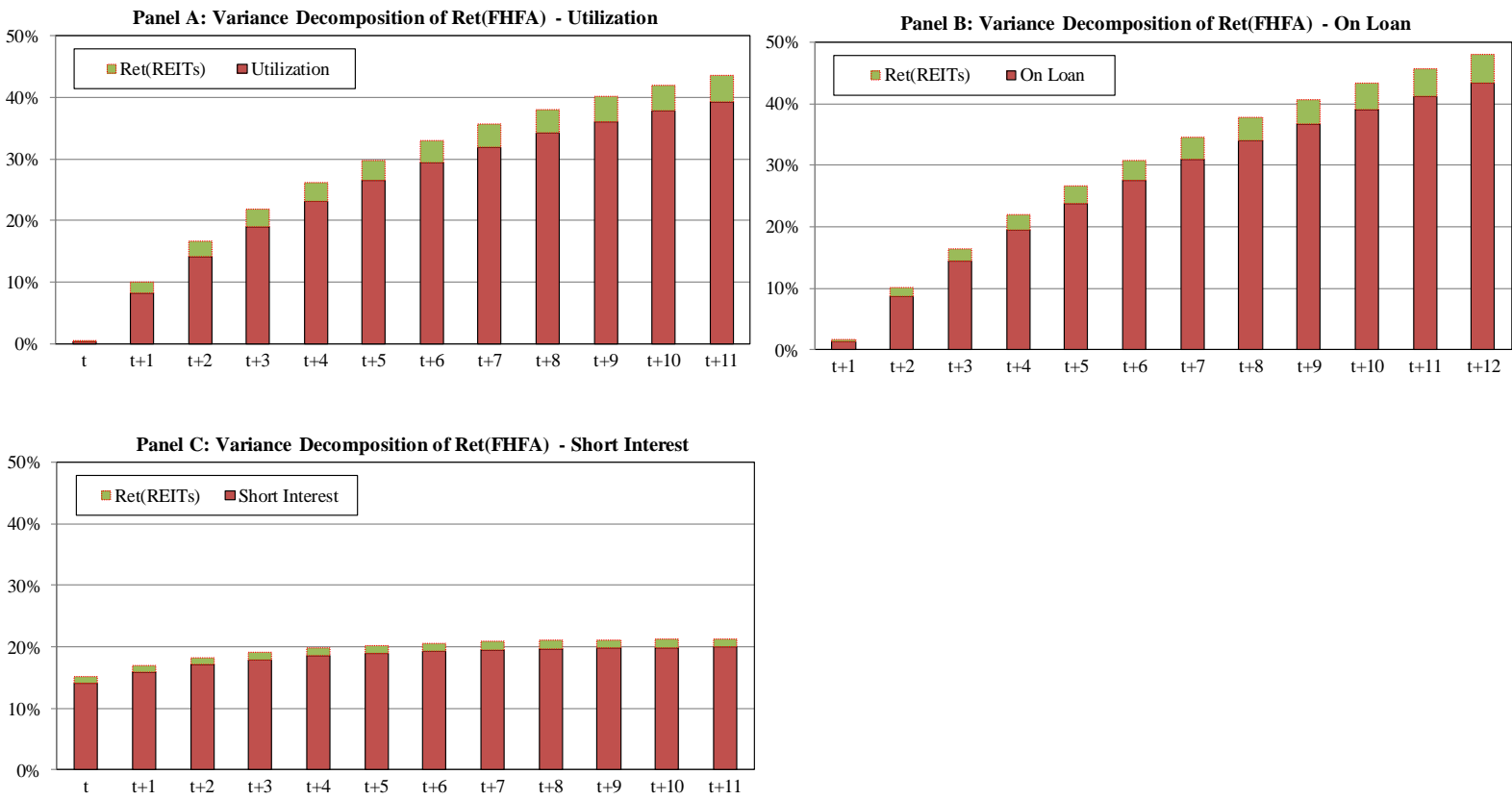
Figure 4. Relative Performance on Long-Only and Hedged Strategies

This figure plots the cumulative performance from July 2007 through July 2013 of the FHFA House Price Index (solid line) and that of a trading strategy that combines a long position in the FHFA House Price Index with a short position on REITs (dashed line). The strategy only shorts REITs when the On Loan measure of short selling intensity of U.S. diversified REITs is 1.64 standard deviations above the 12-month rolling window mean. The strategy is based on shorting 50\% of the amount in the long position. Panel A shows the returns using REITs in each U.S. Census' regions to hedge a long position in individual U.S. Census' regions FHFA House Price Index decreases, while Panel B shows returns using diversified REITs' to hedge against decreases in the U.S. aggregate FHFA House Price Index. On Loan is the number of shares lent out scaled by market capitalization.

Panel A. Cumulative Returns based on Individual U.S. Census Regions Data

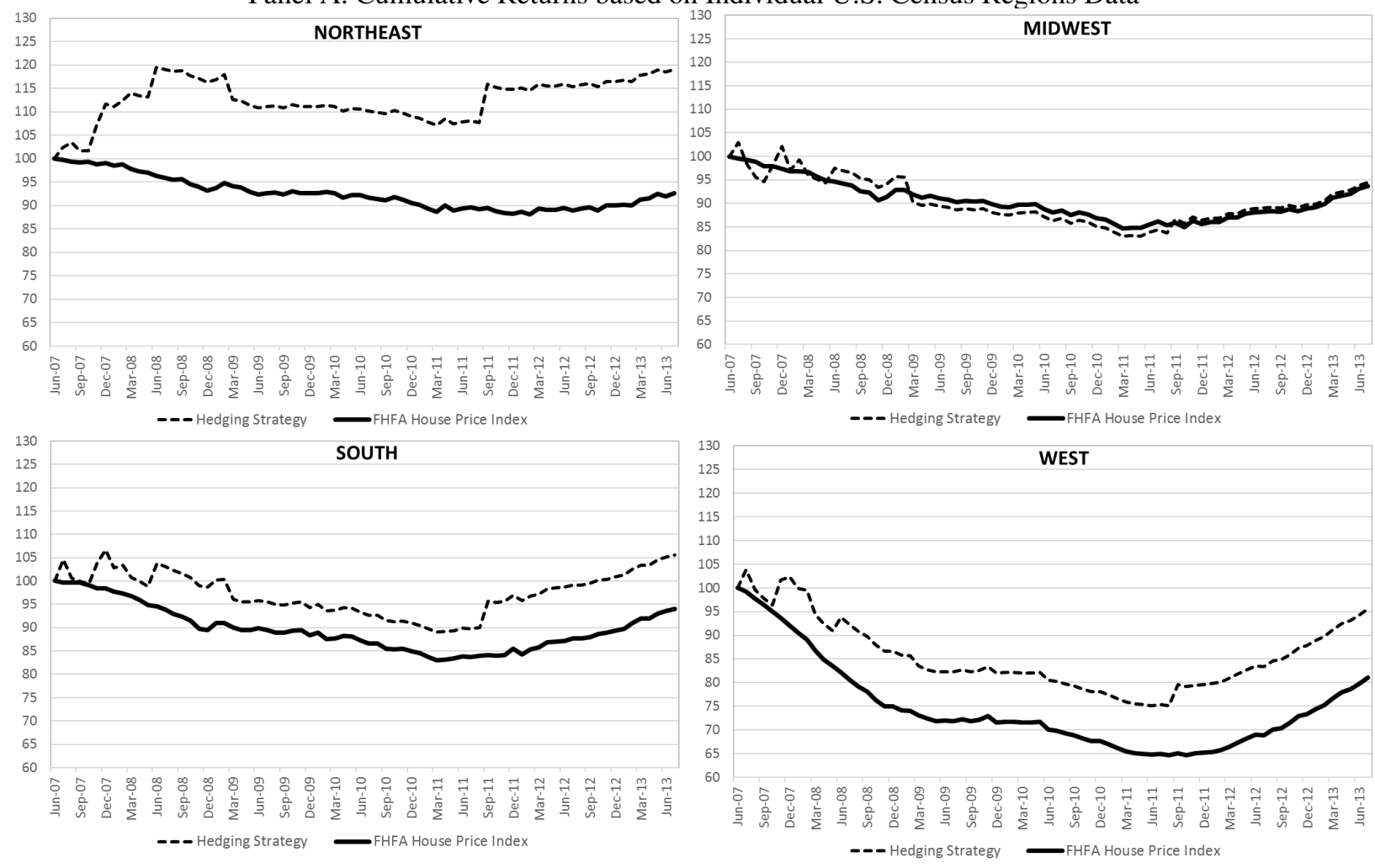

Panel B. Cumulative Returns based on Aggregate U.S. Data

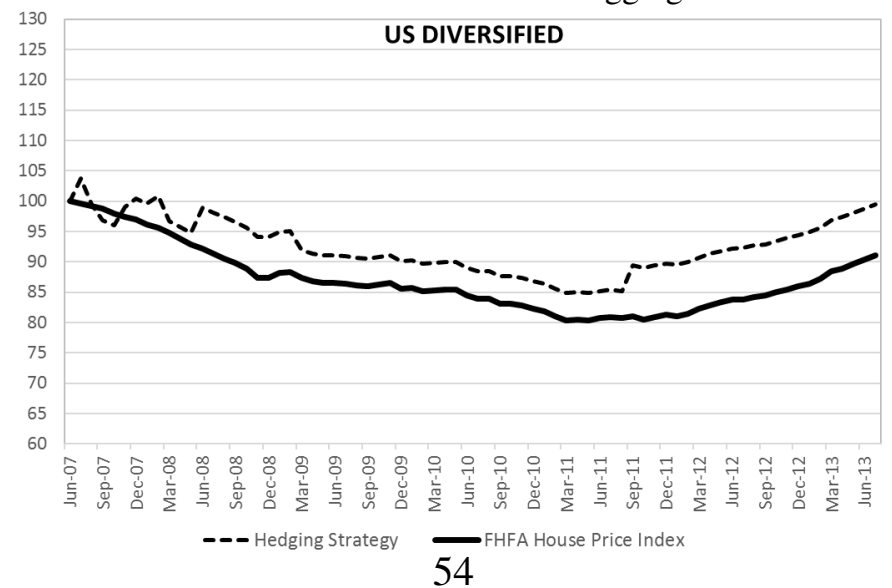

